

\section{DISCLAIMER}

This report was prepared as an account of work sponsored by an agency of the United States Government. Neither the United States Goverament nor any agency thereof, nor any of their employees, makes any warranty, express or implied, or assumes any legal liability or responsibility for the accuracy, completeness, or usefulness of any information, apparatus, product, or process disclosed, or represents that its use would not infringe privately owned rights. Reference berein to any specific commercial product, process, or service by trade name, trademark, manufacturer, or otherwise does not necessarily constitute or imply its endorsement, recommendation, or favoring by the United States Government or any agency thereof. The views and opinions of authors expressed herein do not necessarily state or refiect those of the United States Government or any agency thereof. 


\section{DISCLAIMER}

Portions of this document may be illegible in electronic image products. Images are - produced from the best available original dociument. 


\section{WASHINGTON STATE UNIVERSITY}

\section{United States Transuranium and Uranium Registries}

Innual Report

February 1,2001 - January 31, 2002
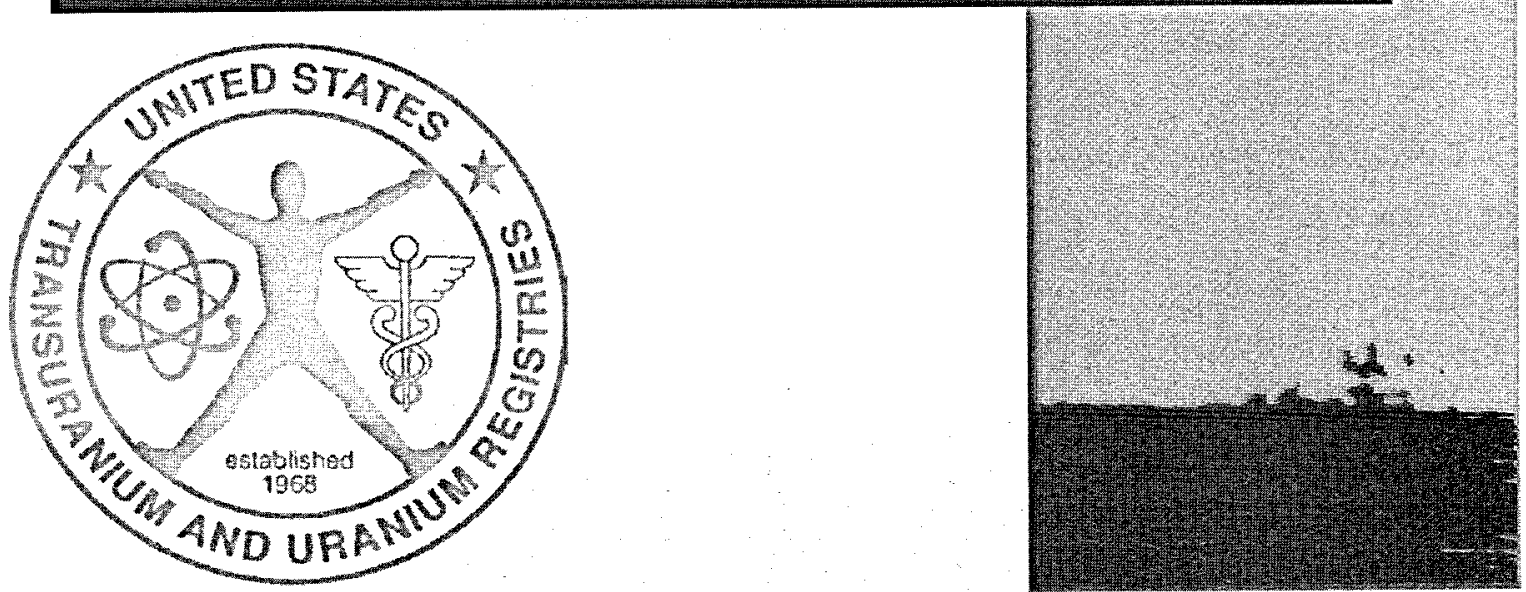

Compiled and Edit ed

Susan M. Ehrhart, Program Administrative Manager

Ronald E Filipy, Director

Contributors

J.R. Al ldredge, T.L. Brumbaugh, S.M. Ehrhart, J.T. Elliston, R.E. Filipy, M.V. Pham, J.J. Russell, R.G. Thomas, and T.G. Wood 
Page 2
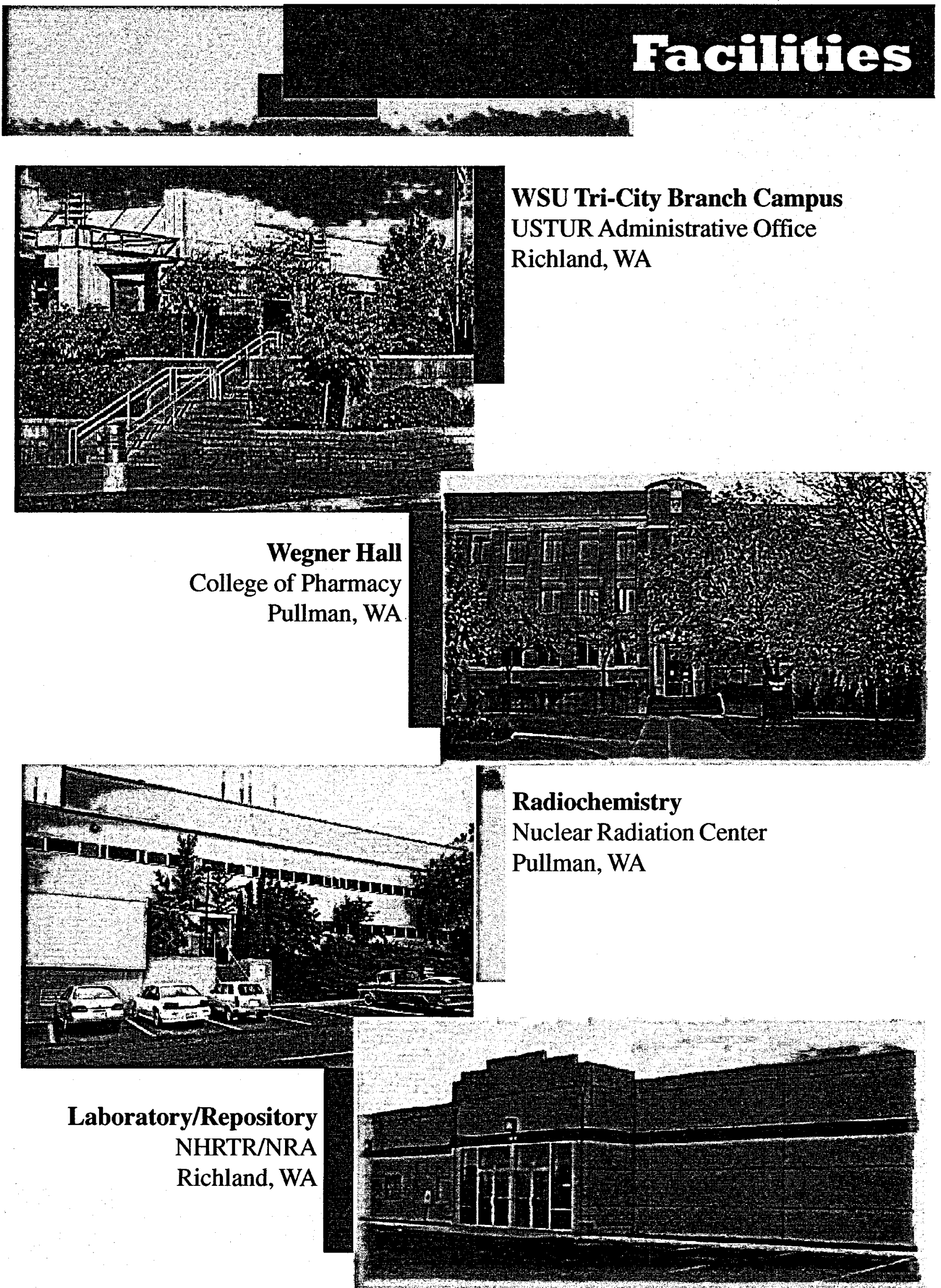


\section{Inside This Report}

Facilities

Inside This Report

Faculty, Staff and Advisory Committee

Contact Information

Director's Message

Highlights of 2001

Financial Report

Registrant Statistics

Information Systems

Scientific Collaborations

National Human Radiobiology Tissue Repository

National Radiobiology Archives

Radiochemistry Operations

Data Management

$\begin{array}{lr}\text { Molecular Biology Applications } & 20\end{array}$

Estimation of Actinide Element Skeletal Content $\quad 21$

$\begin{array}{ll}\text { Incidence of Cataracts } & 25\end{array}$

$\begin{array}{ll}\text { Wound Contamination } & 26\end{array}$

$\begin{array}{ll}\text { Advisory Committee Report } & 27\end{array}$

$\begin{array}{ll}\text { Publications and Presentations } & 38\end{array}$

Appendix A - Abstracts of Published Manuscripts $\quad 40$ 


\section{Faculty, Staff and Hdvisory Committee}

\section{Faculty}

Ronald E. Filipy, Director

John T. Russell, Associate Director

James T. Elliston, Director of Radiochemistry

Dorothy B. Stuit, Radiochemist

Michael E. Aman, Radiochemist

J. Richard Alldredge, Statistician

\section{Hdjunct Faculty}

Alan Birchall, Adjunct Professor

Anthony C. James, Adjunct Professor

Melvin R. Sikov, Adjunct Professor

Gerald E. Dagle, Associate Professor

Baruch Gold, Associate Professor

Mike R. Cummings, Adjunct Assistant Professor

Baruch S. Jacobson, Adjunct Scientist

\section{Administrative Professionals}

Susan M. Ehrhart, Program Administrative Manager

Minh V. Pham, Systems Analyst

Tanya G. Wood, Scientific Assistant

\section{Staff}

Cathy Grimm, Research Technologist

Tawnya L. Brumbaugh, Secretary

\section{Students}

Rosa M. Padilla, Undergraduate Workstudy

Ginger M. Grass, Undergraduate Workstudy

\section{Advisory Committee}

Robert G. Thomas, Chairman

Joe Aldrich, Member

Ronald Brosemer, Member

Kathryn Paxton George, Member

Isabel Fisenne, Member

Bruce Lawson, Member

Dennis Mahlum, Member

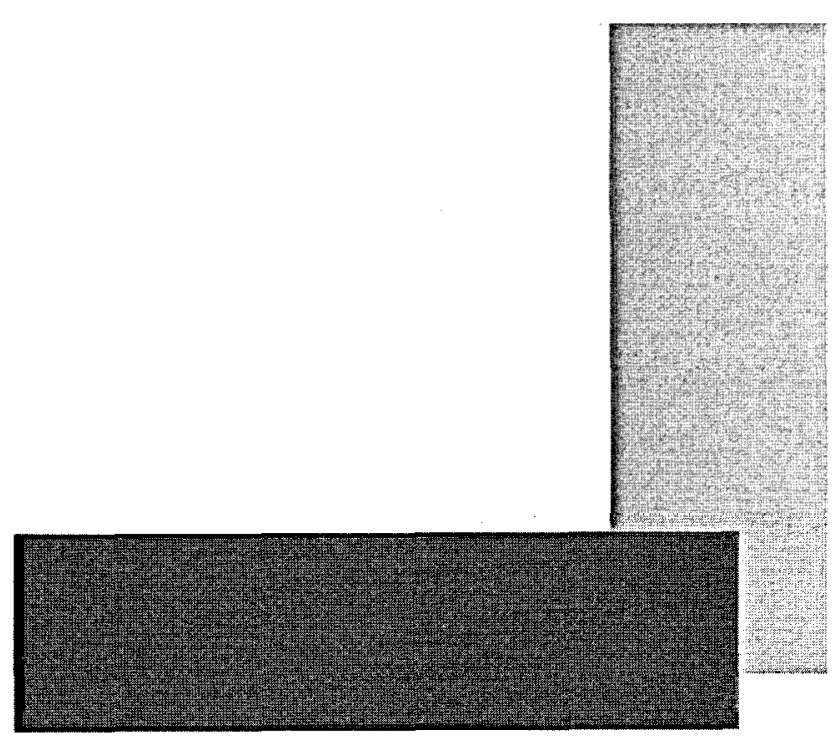




\section{Contact Information}

\section{Address}

Washington State University

2710 University Drive

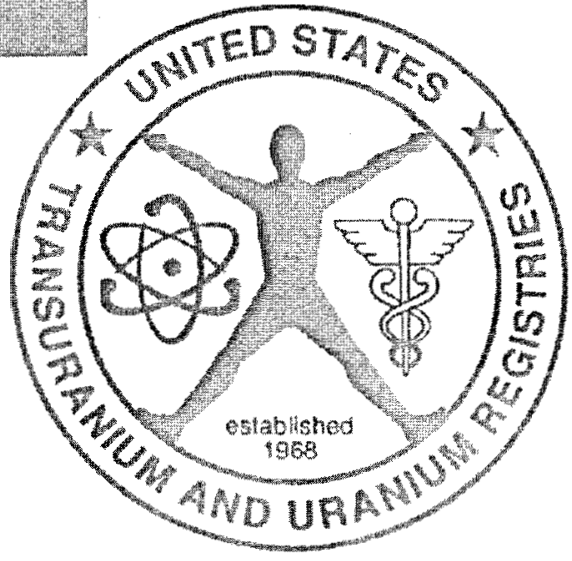

Richland, WA 99352

\section{Phone \\ Toll-Free (800)375-9317 \\ (509)372-7317}

Fax (509)375-1817 or (509)372-7160

\section{World Wide Web www.ustur.wsu.edu}

Alldredge, J. Richard Aman, Michael E. Brumbaugh, Tawnya L. Ehrhart, Susan M. Elliston, James T. Dagle, Gerald E. Filipy, Ronald E. Jacobson, Baruch James, Anthony C. Padilla, Rosa $\mathbf{M}$. Pham, Minh V. Russell, John J. Sikov, Melvin R. Stuit, Dorothy B. Wood, Tanya G.

Amail
alldredg@wsu.edu
maman@mail.wsu.edu
tbrumbau@tricity.wsu.edu
syoung@tricity.wsu.edu
elliston@wsu.edu
gdagle@tricity.wsu.edu
rfilipy@tricity.wsu.edu
bjacobso@tricity.wsu.edu
consult@acj-associates.com
rpadilla@tricity.wsu.edu
mpham@ricity.wsu.edu
jrussel@tricity.wsu.edu
msikov@tricity.wsu.edu
stuit@mail.wsu.edu
twood@tricity.wsu.edu

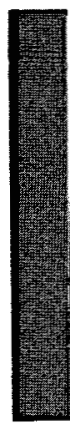




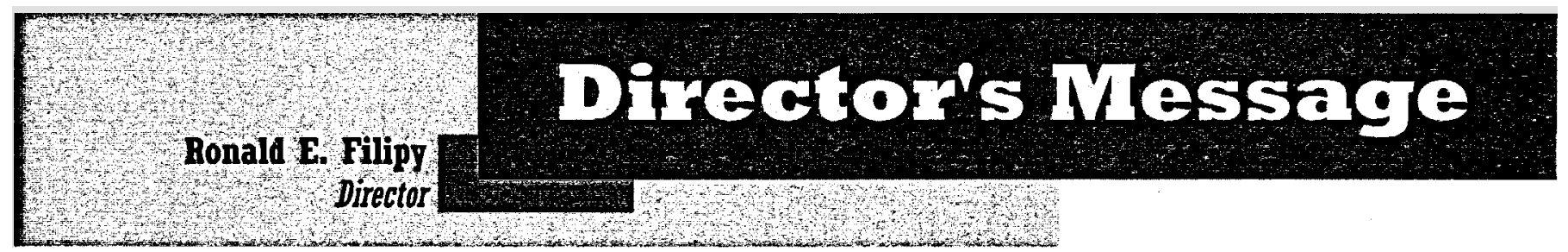

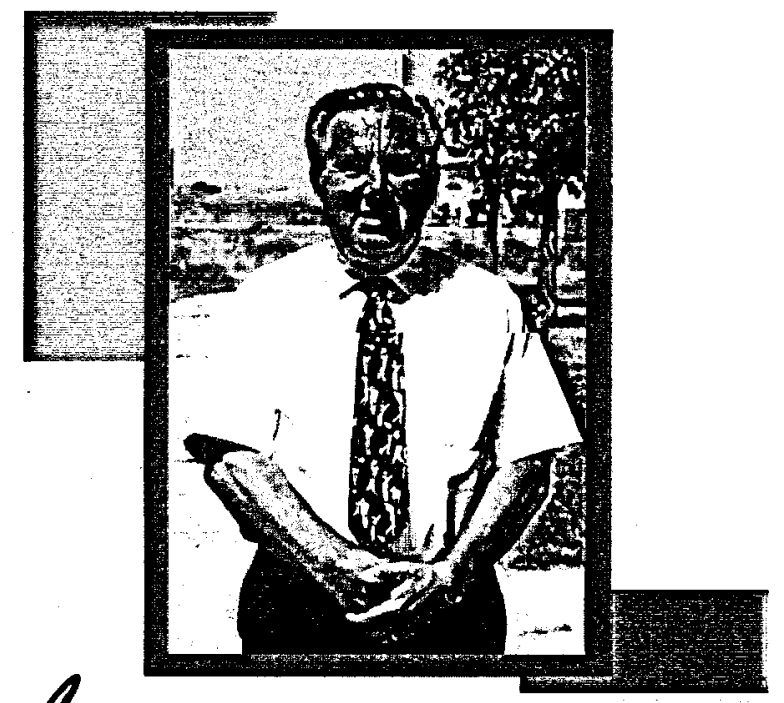

ast year, I put out the call for more collaborative research projects involving the USTUR and other scientists and I briefly described three examples of kinds of projects that would be directly related to the mission of the USTUR. I am pleased to say that we have begun several new collaborative projects since then.

One of those projects is especially exciting in that the results of this project will be of immediate interest to dosimetrists dealing with exposures to actinide elements. The USTUR has collaborative relationships with Los Alamos National Laboratory, the Rocky Flats Former Radiation Worker Medical Surveillance Program, the Savannah River site, and the Hanford site. These relationships facilitate the sharing of bioassay data to compare the in vivo estimates of actinide organ burdens in former workers from those sites with the organ burdens measured by the USTUR in autopsy samples from those workers. Also, the USTUR has a collaborative agreement with the National Radiological Protection Board (NRPB) of the United Kingdom to use USTUR data to assist in testing and contributing to the development of new radiation dosimetry software based on the respiratory tract and systemic biokinetic models currently recommended by the International Commission on Radiological Protection (ICRP). The bioassay analysis software is known as IMBA Expert U.S. DOE Edition (IMBA - Integrated
Modules for Bioassay Analysis) and are currently under development by the NRPB and ACJ \& Associates of Richland, WA. The IMBA models may become the standard for internal dosimetry at all DOE sites. This collaborative project will facilitate comparisons of the results and parameters of the in vivo dosimetry models currently used at four DOE sites with those from the IMBA model and, finally, with the measured results of the USTUR. This kind of project represents the reason for establishment of the USTUR nearly 35 years ago.

One part of the USTUR that is not yet being utilized to its fullest potential is the National Human Radiobiological Tissue Repository (NHRTR). This facility contains donated tissue samples preserved in a frozen state $\left(-70^{\circ}\right.$ C) that could be used for molecular cytogenetic studies of the microscopic and submicroscopic effects of internal alpha radiation. Precise actinide contents of those tissue samples have been measured so that radiation doses can be easily calculated. We are aware that this facility has a counterpart in the former Soviet Union, the Russian Human Tissue Repository; however, the Russian repository contains primarily fixed tissues that may not be suitable for some cytogenetic studies.

Inquiries regarding collaborative projects are always welcome. Telephone numbers, e-mail addresses, and mailing addresses are included in this report.

Let's hear from you! 
UNITED STATES TRANSURANIUM HND IRANIUM REGISTRIES

PHARMACEUTICAL SCIENCES

COLLECE OF PHARMECY

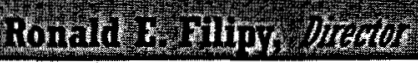

\section{Highlights of 2001}

\section{Grant Renewal}

The major highlight of the past year was the preparation of a proposal to the U.S. Department of Energy for continued operation of the USTUR by the Washington State University College of Pharmacy, and the acceptance and funding of that proposal by the U.S. DOE. The proposed work included 19 specific tasks in 5 major areas of operation of the program during the years $2002-2005$. The majority of the tasks involve research collaborations with other scientists, both nationally and internationally. Many such projects have already been established with others still in the planning stages. It is hoped that, through these collaborative projects, USTUR data will become more available to organizations such as the National Council on Radiation Protection and Measurements (NCRP) and the International Commission on Radiological Protection (ICRP).

\section{Extensive Use of USTUR Data}

The latest version of the Toxicological Profile for Americium was published by the U.S. Department of Health and Human Services, Public Health Service, Agency for Toxic Substances and Disease Registry during 2001. This version contained more than 20 references to scientific papers published by USTUR staff members and that was one of the first such extensive uses of USTUR data. These Profiles are revised and republished as necessary but no less than once every three years. Revision of the Toxicological Profile for Plutonium is underway and the USTUR was asked to provide information and publications for that revision. A primary mission of the USTUR is to make data available to all such organizations.

rod by the us. ise

\section{Wô Registrant Categorization}

aid

cors thafficult procedure during the past year involved termibt in natiófóf autopsy agreements with over 50 USTUR Regreonistránts. Malny of those Registrants had participated in the USTUR for several decades and termination of their agreements was not an easy decision; however, it was largely driven by the need to preserve funds for analysis of the more highly exposed cases. The work histories and radiation exposure information of all USTUR Registrants were evaluated and those with the least likelihood of significant body burdens of the actinide elements were selected for termination of agreements. In the early days of the USTUR, all interested individuals were accepted as a Registrant with the idea that those with very low body burdens would represent background levels of actinide intake. The USTUR now has a sufficientamount of information about background levels and performance of autopsies and radiochemical analyses of more cases is not cost effective.

\section{NHRTR Inventory}

A complete inventory of the holdings of the National Human Radiobiological Tissue Repository was completed and computerized during the past year. The inventory list includes frozen tissue samples, acid-dissolved tissue solutions, paraffin tissue blocks, and microscope slides as well as other materials collected over the years. This will facilitate establishment of collaborative research projects with molecular geneticists and other users of NHRTR materials.

\section{Public Inquiries}

The USTUR received a number of phone calls from individuals interested in the Energy Employees Compensation Act with the mistaken impression that the USTUR was involved in the administration of that program. This program is administered by the U.S.Department of Labor (DOL), which has four district of fices and 10 local resource centers throughout the country Claim forms may be obtained through the DOL web site at www.dol.gov or requested by a Tollfree telephone call to 866-888-3322, in: 
Susan M. Ehrhart

\section{Inancial Report}

Program Administrative Manager

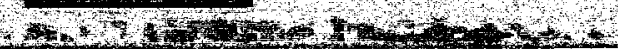

\section{FY01 Funding}

\section{Federảl Resources}

\section{Grant}

U.S. Department of Energy

Office of Health Studies

Management and Operation of the United States

Transuranium and Uranium Registries

DE-FG06-92EH89181

Amount Awarded: $\$ 1,003,020$

Period: 02/01/01-01/31/02

\section{Grant}

U.S. Department of Energy

Office of Biological and Environmental Research

Operation of the National Radiobiology Archives

DE-FC03-96ER62213

Amount Awarded: $\$ 50,000$

Period: 01/01/01-12/31/01

\section{Subcontract - Federal Flow-down}

University of Colorado

Health Sciences Center

Uncertainty Analyses to Characterize Plutonium

Exposure

R01-CCR815762

Amount Awarded: Pending Negotiation

Period: 08/01/01-07/31/02

\section{Table 1 Historical Operating Budget}

Fiscal Year Total Operating Budget FY98 $1,256,978$

FY99

$1,121,528$

FYO0

FY01

$1,075,001$

$1,053,020$

\section{Sources of USTUR Funds}

Fintro:

\section{Current funds for FYOI}

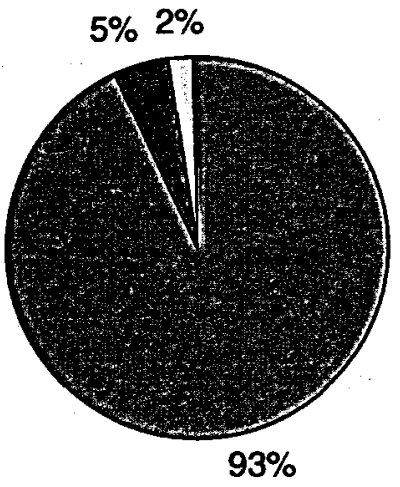

⿴囗口 DOE Office of
Health
DOE Office of
Biological and
Environmental
Research
University of
Colorado

\section{Grant and Contract Administration}

During FY01 USTUR submitted 2 federal proposals and 1 federal flow-down subcontract to extramural sources for a total amount requested of $\$ 1,191,939$. Both federal proposals were funded for a combined total of $\$ 1,053,020$ (Table 1, Figure 1). The subcontract was accepted and is 6 months into the term but the funding level is still pending negotiation.

\section{FTE Reduction}

The USTUR had a $16 \%$ decrease in program source funding from grants and subcontracts compared to the level of funding received in FY98. This decreased level of funding significantly impacts the Full Time Employee (FTE) level that the USTUR can support from 13.05 FTE in FY98, 14.37 FTE in FY99, 10.09 FTE for FY00 to the present 8.75 FTE for FY01.

\section{Financial Reports}

Monthly financial status reports were prepared and distributed to the investigators and sponsoring agencies on a monthly basis. The financial status reports provide information on total obligations, monthly expenditures, expenditures year-to-date, encumbrances year-to-date and available funds. 


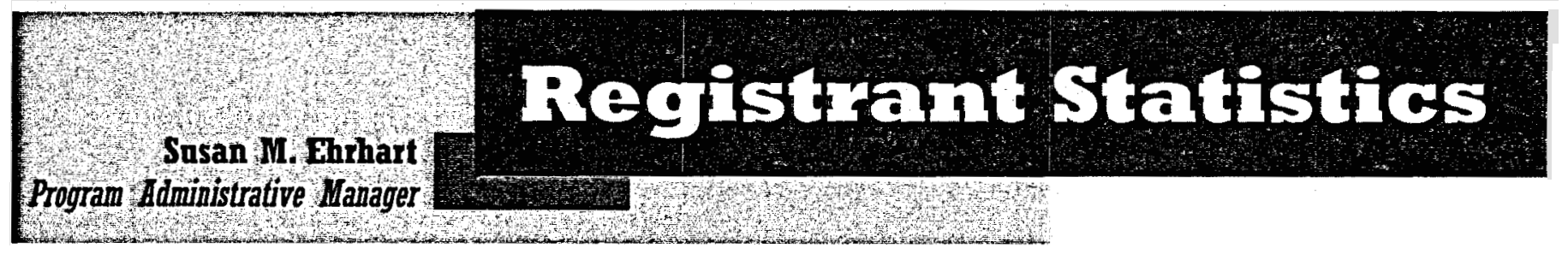

\section{Registrant Statistics}

As of January 31, 2002, the Registries had a total of 911 Registrants in all categories. Of that number 140 were living Registrants and 350 were deceased Registrants. There were 420 Registrants in an inactive category. The inactive category includes the $54 \mathrm{Cat}-$ egory $3 * * *$ Registrants that were placed inactive as of December, 2001.

The table to the right (Table 2) lists the number of Category $1 *$ and $2 * *$ Registrants per worksite for the living Registrants. The pie graph (Figure 3) represents the total number of Category 1 and 2 Registrants. The figure below (Figure 2) shows the Registrant status (living or deceased) by worksite.

*Significant actinide exposure with past or present positive bioassay results.

**Relatively high external radiation dose or professed exposures to beryllium, asbestos, or chemical solvents, but with minimal body burdens of the actinide elements.

*** Not likely to have had any intake based on bioassay results and work histories.

\section{Gure 2 Status of Tissue Donors by Site}

\begin{tabular}{|c|c|c|}
\hline te & ory 1 & \\
\hline $\begin{array}{l}\text { Fernald, } \\
\text { Manford } \\
\text { Los Alamos } \\
\text { Mound } \\
\text { Oak Ridge } \\
\text { Rocky Flats } \\
\text { Savannah River } \\
\text { Uranum Mline Workers } \\
\text { Nevada Test Site } \\
\text { Special Cases } \\
\text { Other }\end{array}$ & $\begin{array}{c}1 \\
22 \\
14 \\
5 \\
3 \\
48 \\
7 \\
5 \\
1 \\
5 \\
4\end{array}$ & $\begin{array}{c}0 \\
15 \\
0 \\
1 \\
0 \\
3 \\
6 \\
0 \\
0 \\
0 \\
0\end{array}$ \\
\hline
\end{tabular}

\section{Living Registrant Categorization}

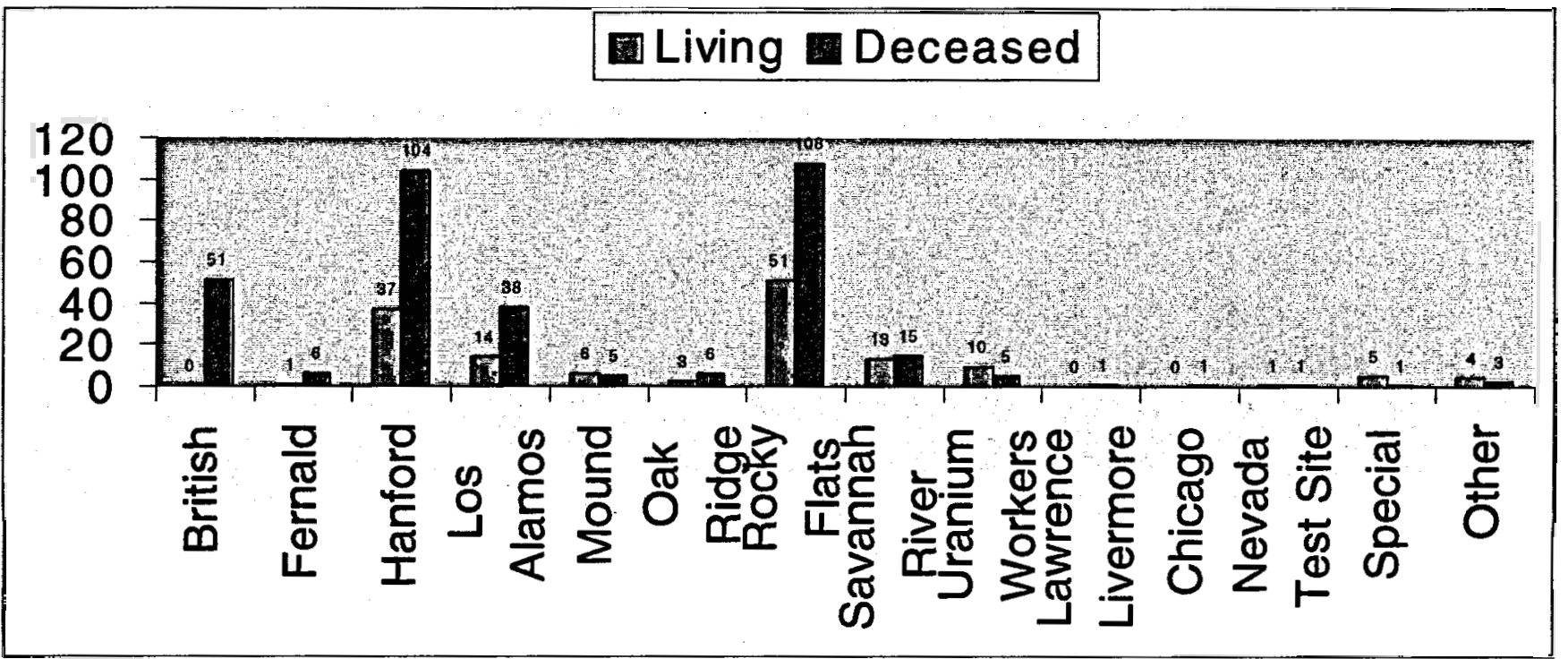


Tawnya L. Brumbaugh Secretary

Minh V. Pham

\section{Information Systems}

\section{Network, Website and Database}

\section{Website}

The USTUR database and website have both continued to grow over the past year. With the continuing addition of information to the website it has grown to approximately $6,000+$ links (see figure 4). The Registries continue to update bimonthly and monitor for traffic, interest and hits per month. The website receives an average of 300-500 hits per month with a total of 5300 for last year (see figure 5). The website also offers numerous links for interested parties to request specific publications and contact information for USTUR faculty and staff. The Registries strive to continue to provide an informative look at what the USTUR is and what valuable and unique resources are available for possible research collaborations.

\section{Gigure 5 Website Statistics for FY01}

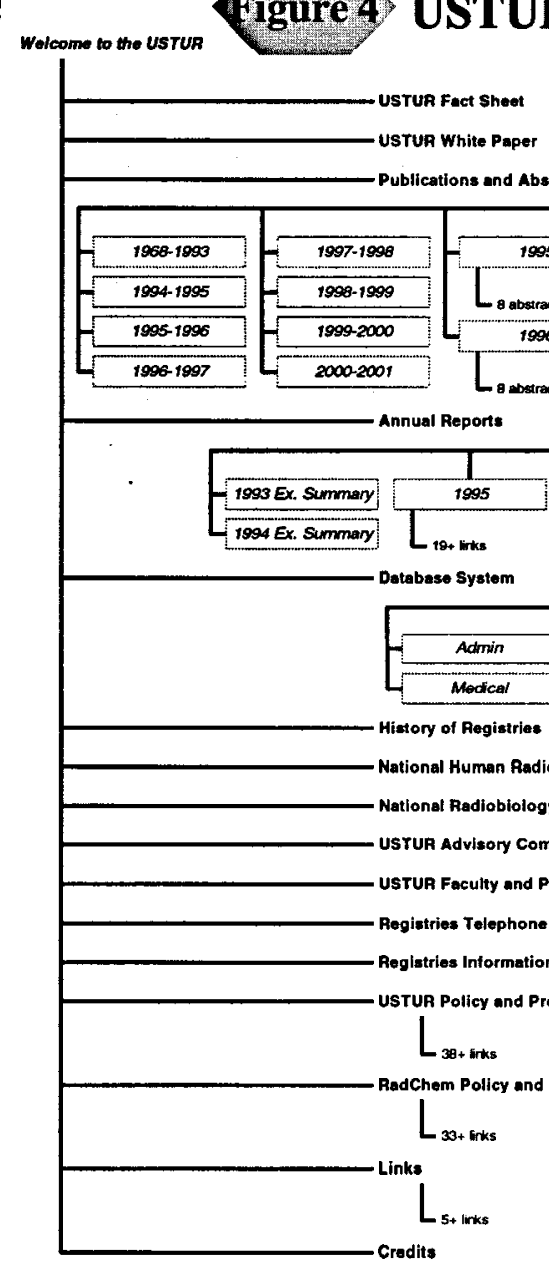

\section{USTUR Homepage Statistics}

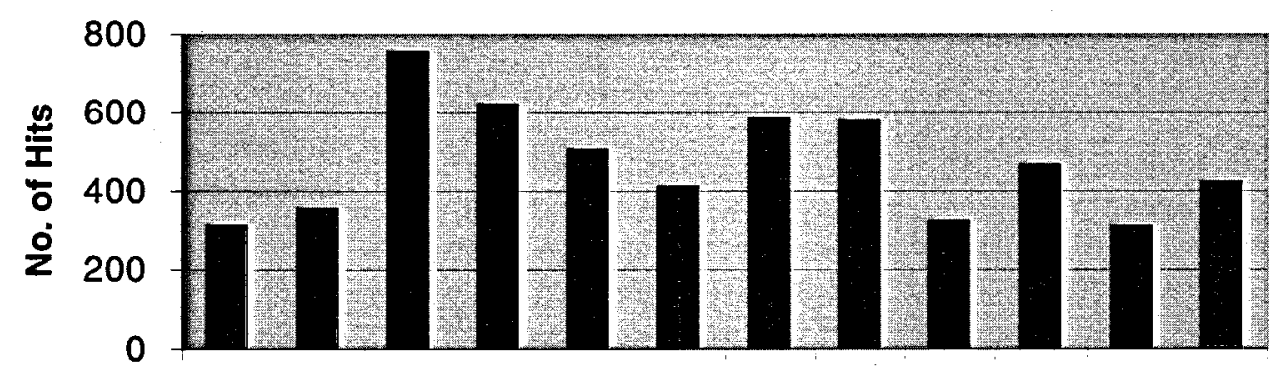

Feb Mar Apr May Jun Jul Aug Sep Oct Nov Dec Jan

\section{(igure 4) USTUR Website Flow Chart}




\section{Network Security}

The Registries took extra network security measures regarding the database and the USTUR internal network against hackers and intruders during FY01. Due to the nature of the Registries' data, security and protection of the USTUR data is crucial to the operation of the program. An evaluation of the USTUR infrastructure indicated several places for improvement. The wiring on the USTUR panel and the connections to the network computers were category 3 with a maximum speed of 10 $\mathrm{MB} / \mathrm{s}$. In addition, the Network Interface Card (NIC) had the capacity of $10 \mathrm{MB} / \mathrm{s}$, which was out of date with the current technology. The solution to this problem was to upgrade all the NIC's to $10 / 100 \mathrm{MB} / \mathrm{s}$, forcing all the NIC's to communicate at this rate. The cables were rewired to category $5 \mathrm{E}$, which has a potential speed from 10 to $1000 \mathrm{MB} / \mathrm{s}$. The Registries intend to upgrade to 1 $\mathrm{GB} / \mathrm{s}$ in the near future when the current cost becomes more reasonable.

\section{Database Update}

Accessing the USTUR database in an efficient time frame also became a major concern during this past fiscal year. The USTUR Access database grew daily with the incorporation of the Health Physics, Medical and RadChem databases now linked with the main USTUR Administrative database. Accessing and querying the data became a time consuming task.

An additional firewall and switch were installed on the USTUR network. These additional devices not only support the private channel to the USTUR database, which increases the speed tremendously compared to the old standard unmanaged hub, but it also acts as a firewall stopping all outside computer traffic from accessing the internal networking system. This upgrade continues to allow Registries personnel access to outside sources such as the WSU services and the Internet.

\section{Visit us at:}

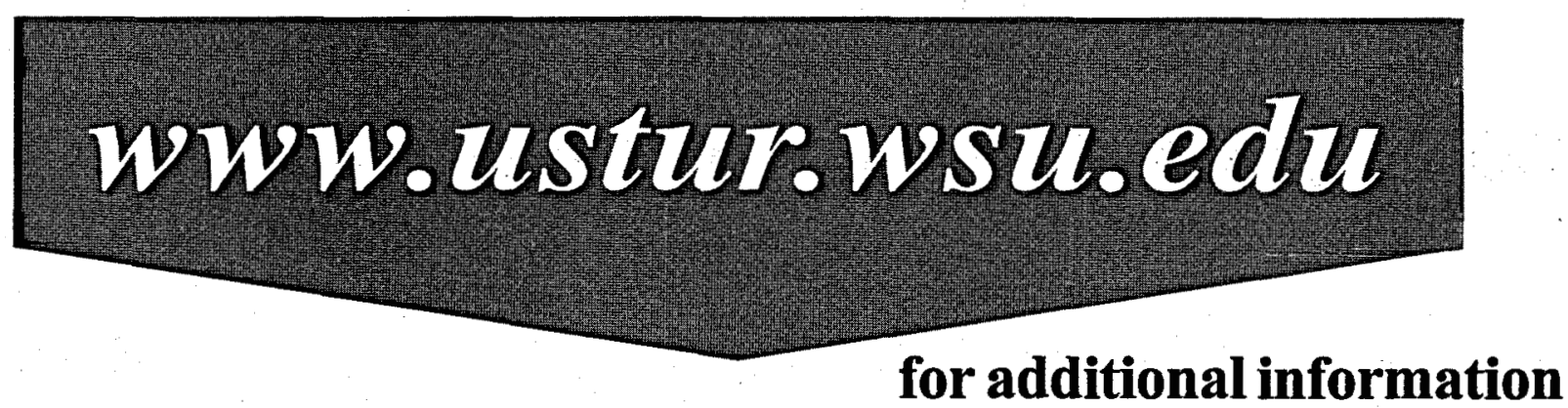


Susan M. Ehrhart

\section{Soientifta Collaborations}

\section{Collaborative Research Projects}

The following collaborative research projects have signed confidentiality agreements (USTUR PPM F106) or have a Memoranda of Understanding on file that insures the protection of Registrant indentities. Research collaborators have also provided written assurance that the Registries' policies with respect to human subjects, informed consent, privacy of the Registrants and their next-of-kin, and national security will be followed as agreed.

\section{University or Colorado}

\section{University of Colorado}

Health Sciences Center

Denver, CO

Dr. James Ruttenber

Objective: Conduct epidemiologic studies at the Rocky Flats Environmental Technology site to explore important issues of measurement errors in quantifying exposures and their effects on estimates of risk in epidemiology studies. The USTUR provides bioassay data in support of this project.

\section{Brookhaven National Laboratory}

Brookhaven, NY

Dr. Casper Sun

Objective: Plutonium deposition and retention in USTUR human placenta as determined by fission track analyses performed by Brookhaven and University of Utah laboratories. Manuscript completed and submitted for publication.

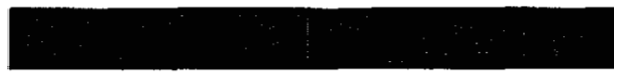

Oak Ridge Associated Universities Arvada, CO

\section{Dr. Nancy Daugherty}

Objective: Conduct case studies to compare in-vivo estimates of actinide body burdens with those measured, after death, by the USTUR in former Rocky Flats workers who are USTUR tissue donors. The USTUR provides the radiochemical analytical data results from tissues of Rocky Flats donors in support of this project.

\section{University of Utah}

Salt Lake City, UT

Dr. R. Lloyd

Dr. Scott C. Miller

Objective: Microdosimetry and microdistribution of plutonium in human bone. The first series of Neutron-induced autoradiographs of $\mathrm{Pu}$ distribution in one USTUR bone sample and one from MAYAK were completed during the first year and additional USTUR bone samples are currently under study.

\section{Medical College of Ohio \\ Toledo, $\mathrm{OH}$}

\section{Dr. James Hardwick}

Objective: Molecular genetic studies of Registrant tissues. Submitted a collaborative proposal to extend previous studies by determining the biological effects of alpha radiation on cell division cycle control and DNA repair genes determining whether increased DNA methylation is a dose dependent phenomena in $\mathrm{Pu}$ exposed individuals. 
Health Protection Bureau

Human Monitoring Laboratory

Ottawa, Ontario CANADA

Dr. Gary Kramer

Objective: The USTUR is providing the materi-

als for construction of a skeletal calibration phan-

tom.

\section{Washington State University}

Washington State University

Department of Chemistry

Pullman, WA

Dr. Sue Clark

Objective: Preparation of external quality assurance/quality control samples for the USTUR radiochemistry protocols in known matrices.

\section{National Radiation Protection Board}

Chilton, UNITED KINGDOM

\section{Dr. Alan Birchall}

Objective: Use of USTUR data to characterize the biokinetics of actinide elements and evaluate models proposed by the National Radiation Protection Board (NRPB).

\section{Pacific Northwest National Laboratory}

Mr. Tim Lynch

Objective: Americium special study case. An accidental americium (Am) inhalation exposure case. The Registries and PNNL have been monitoring this case from approximately 48 days post accidental intake. The Am inhalation accident occurred in 1996. A manuscript describing this case was prepared and submitted for publication.
To maximize the scientific worth and output of the unique materials and data under their purview, the Registries encourage and actively seek collaboration with other investigators and institutions.

New York University

Stoneybrook, NY

Dr. Gerald Abraham

Objective: To determine what fraction of USTUR lung tissue samples contain asbestos fibers. Secondly, what fraction of lung tissue samples containing asbestos fibers also display fibrosis? Ultimately to determine if the level of fibrosis is related to the specific activity of the lung tissue sample.

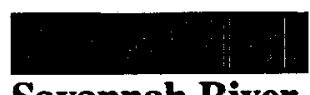

Savannah River

Aiken, SC

Mr. Tom LaBone

Rocky Flats

Golden, $\mathrm{CO}$

Mr. Roger Falk

Los Alamos

Los Alamos, NM

Mr. Guthrie Miller

Hanford

Richland, WA

Mr. Gene Carbaugh

AC James and Associates

Richland, WA

Dr. Anthony C. James

Objective: Comparison of estimated actinide element body and organ burden made with various methods at DOE worksites with the burdens measured, after death, by the USTUR. 


\section{Laboratory Operations}

\section{Registrant Deaths}

During this report period, the NHRTR arranged autopsy services and tissue acquisition for nine Registrants who died during the period; one case was rejected because it was highly infectious and another because the family had a change of heart and wished to no longer participate in the program. None of these cases were whole body donations.

\section{Laboratory Inventories}

A thorough inventory of all 17 freezers was completed during this fiscal year. The samples were sorted by case number and placed together in a large bag with a tag identifying each case. The contents of each of these case bags was also inventoried and logged into the main USTUR database, where now, at the click of a button, one can access information about the tissues that the USTUR has available.

The USTUR's collection of environmental sample solutions was also inventoried and checked against a list that was acquired from Los Alamos National Laboratory (LANL). Each box was repacked, labeled, and the contents (bottle numbers) listed on the outside of the box. An electronic catalogue facilitates rapid location of specific sample solutions. An inventory of National Radiobiology Archives (NRA) document holdings was completed as well and the next step will be getting this information in a user-friendly computer format. Also, during the next fiscal year, an inventory of the NRA slides and paraffin blocks will be completed and added to the database.

\section{Uranium Analyses}

The Pennsylvania Department to Environmental Protection (PDEP) contacted the Registries with a request for analyses of some urine samples from a Pennsylvania family. They explained that the family had contacted their office about elevated uranium levels in their hair. The family's doctor had submitted samples of their child's hair for trace metal analysis and an independent laboratory indicated "elevated" levels of uranium in the sample. A second independent laboratory obtained a value of $2.4 \mathrm{mg} \mathrm{U} / \mathrm{g}$ hair; however, neither laboratory gave any specific information about the analytical methods used or standards used for comparison. In addition, the PDEP office detected elevated levels of radioactivity in the drinking water in the family's home.

The USTUR sent urine collection kits to the three family members and analyzed the samples by kinetic phosphorescence analysis (KPA) when they were returned. The average result for the three family members was approximately $25 \mathrm{ng} \mathrm{U} / \mathrm{L}$ indicating excretion of approximately $1.4 \mathrm{ng} \mathrm{U} /$ day or $\sim 1 \mathrm{mBq}$ in terms of radioactivity from natural uranium. The US Environmental Protection Agency (1991) proposed a maximum concentration limit of $20 \mathrm{mg} / \mathrm{L}(\sim 1 \mathrm{~Bq})$ for naturally occurring uranium in drinking water and, assuming that urinary excretion of uranium approximates the intake from drinking water, it was concluded that the family was not ingesting an excessive amount of uranium and the hair sample was contaminated from an external source.

The USTUR has received many calls regarding "high" uranium content of hair samples from members of the public. Apparently, there are a group of medical practitioners in the U.S. who routinely submit hair samples from patients for trace metal analysis. The patients usually suffer from non-descript symptoms, such as malaise, lack of energy, and assorted allergies. Registries personnel usually express the need for caution in accepting the results from such analyses without knowing how the sample was handled prior to analysis and without information about the analytical methods that were used. 


\section{National Radiobiology Hrchives}

\section{Program Background}

The National Radiobiology Archives (NRA) is an archival program that was started in 1989 and whose original mission was to collect, organize, catalog data, lab notebooks, and animal tissue specimens from government (Department of Energy and its predecessor agencies) sponsored radiobiology life-span studies performed at various national labs and university facilities since the 1940's. Thus, these valuable archived records, histopathology slides and paraffin embedded tissue blocks are stored and maintained in a centralized facility and are available for additional future research and or analyses if and when needed. Although these studies were performed over many years and at different laboratories with differing data managment systems, the NRA has translated them into a more convenient set of relational database tables, which can be distributed to interested individuals following a written request.

Since transfer of the NRA to Washington State University (WSU), the USTUR has actively promoted and publicized the availability of these materials by USTUR and other researchers. In addition, the Registries have developed a brochure that describes the NRA program. The brochure is featured on the USTUR Website and is otherwise distributed to potential clients.

\section{Public Requests}

Several individuals seeking NRA data and or information have contacted the program during the past year. Some of the more significant requests are described briefly below.

Dr. Shin Saigusa, Japan Atomic Energy Research Institute, arranged to visit the NRA and the USTUR in the spring of 2002 to learn more about the animal and human tissue archives. Dr. Saigusa will have a new position at the National Institute of Radiological Sciences (NIRS) and will be tasked with establishing an animal tissue archive and, possibly, a human tissue archive later. The purpose of his visit was to learn about the current policies and procedures for acquiring and maintaining animal tissue samples or blocks for the NRA, how they are stored and for how long. He was also interested in the data files or records that contain information such as histopathological diagnoses, radionuclide content, dosimetry, sacrifice schedules and experimental design. In addition, the policies and procedures of the Registries regarding distribution or dissemination of information or sample materials to those members of the scientific community who request them were discussed. And, finally, the frequency of requests for information or tissue material from the NRA archive on an annual basis was of interest. According to Dr. Saigusa, several Japanese researchers have expressed an interest in possibly requesting tissue samples from the NHRTR and the NRA. The success of the USTUR archives, both animal and human, will serve as a model for their new venture.

Dr. Bruce Madewell, University of California, UC Davis contacted the program seeking canine tissue specimens from the NRA. Dr. Madewell is interested in examining canine prostate glands in an effort to search for histologic evidence of prostatic intraepithelial neoplasia, which is an important lesion in human urology and is considered a precancer. Dr. Madewell was informed that the NRA collection no longer includes any fixed-tissue specimens, either rodent or canine, but does maintain a small collection of stained slides and paraffin blocks from some of the animal experiments performed at PNNL. Dr. Madewell and his associates had utilized fixedtissue specimens from the NRA in the past before they were disposed of and the program was transferred to WSU. 


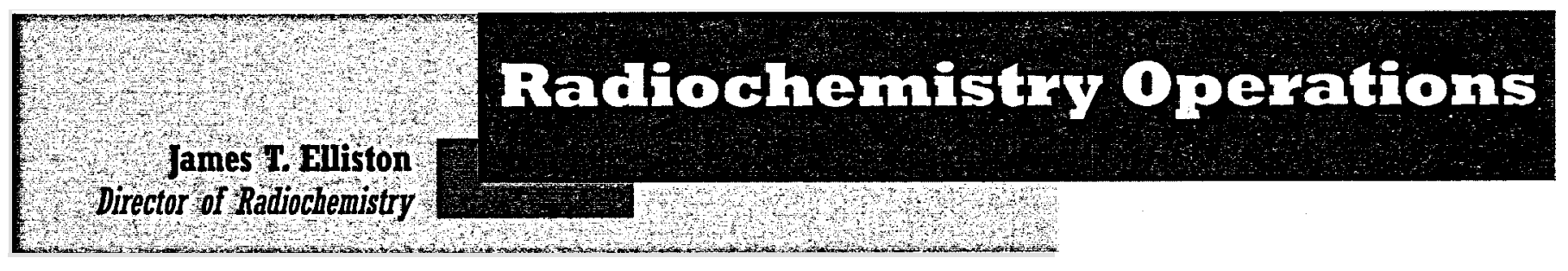

\section{Radiochemistry Operations}

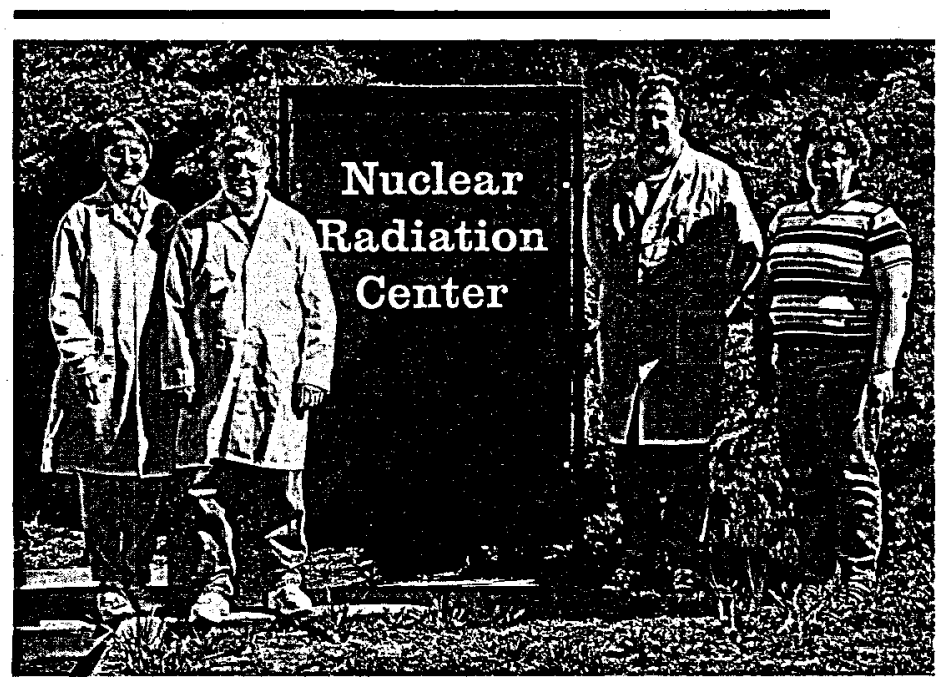

\section{Mission}

The mission of the Radiochemistry group is to analyze human tissues donated to the USTUR from workers who were occupationally exposed to americium, plutonium, thorium, and/or uranium. The data from these analyses are used to verify and refine biokinetic models that describe the deposition and translocation of these nuclides in the human body.

\section{Background}

The end of 2001 marked over 32 years of radioanalytical measurements of actinides in human tissues for the U.S. Transuraniumand Uranium Registries since its inception in 1968. The Radiochemistry Program for the USTUR was transferred to Washington State University, Pullman, WA from Los Alamos National Laboratory in 1994 and continues to be housed at the Nuclear Radiation Center of Washington State University. In the last eight years the radiochemistry program has been successful in developing a quality laboratory, reducing the backlog of samples awaiting analysis, developing new separation methods, publishing, and participating in the graduate and undergraduate educational process at Washington State University. It is anticipated that in excess of 300 samples will be processed during the forth-coming project year.

\section{Case Analyses}

Cases for sample analyses are divided into three categories: Routine Cases, Prioritized Routine Cases, and Whole Body Cases, based on the expected body burdens predicted by positive bioassay results in occupational records.

\section{Routine Cases}

The expedited analysis protocol (EAP) for Routine Cases generally involves analyses of $4-5$ samples from each case for radionuclides suspected to be predominant in the samples. Samplestypically include the lungs, pulmonary lymph nodes, liver, and 1-2 bone samples to establish an estimate of the body burden. Analyses of the following cases were completed by EAP and reported during the project year:

Case 0302: A routine Registrant from Hanford.

Case 0331: A routine Registrant from Hanford.

Case 0423: A routine Registrant from Rocky Flats.

Case 0444: A routine Registrant from Rocky Flats.

Case 0672: A routine Registrant from Los Alamos, which was moved to the priority list because of the results from the EAP.

Case 0709: A routine Registrant from Hanford, which was moved to the priority list because of the 
UN ITED STATES TRANSURANIUM HND URANIUM REGISTRIES

PHARMACEOTICAL SCIENCES

COLLEGE OF PHARMACY

results from the EAP.

Case 1066: A special uranium urine case from Pennsylvania.

\section{Prioritized Routine Cases}

The USTUR Radiochemistry group has been analyzing routine autopsy cases by the EAP since 1997. Four to five samples from each of 50 Routine Cases have been radiochemically analyzed to date. Thus far, 17 of the Routine Cases evaluated have body burdens estimated at greater than $1000 \mathrm{dpm}$ at death $(17 \mathrm{~Bq})$. Activities less than $1000 \mathrm{dpm}$ make precise measurement of the actinide content in other tissues difficult and the remaining analyses for these cases have been assigned a very low priority.

\section{Whole Body Cases}

Reduction in the backlog of whole body cases continues to be one of the primary goals of the USTUR Radiochemistry Program. In keeping with this goal, samples from six whole body cases were completed or were being processed during this project year. Typically the tissues analyzed for a whole body case include half of the bones and all of the major organs. Cases in process include:

Case 0425: A male whole body donation from Rocky Flats was completed and reported. This case was analyzed for americium, plutonium and natural uranium.

Case 0503: A male whole body donation from Rocky Flats: the initial survey of five samples gave a whole body activity estimate of $34,000 \mathrm{dpm}(570 \mathrm{~Bq})$.

Case 0635: A male whole body donation from Los Alamos: the initial survey of five samples gave a whole body activity estimate of $65,000 \mathrm{dpm}(1100 \mathrm{~Bq})$.
Case 0680: A male whole body donation from Los Alamos: the initial survey of five samples gave a whole body activity estimate of $98,000 \mathrm{dpm}(1600 \mathrm{~Bq})$.

Case 0682: A male whole body donation from Mound Laboratories who was exposed to ${ }^{238} \mathrm{Pu}$ as a result of a glove box explosion. Preliminary results show that there are several dpm of ${ }^{238} \mathrm{Pu}$ per gram of bone ash. All of the samples for this case have been dissolved and analyses are in process.

Case 0706: A male whole body donation from Rocky Flats: the initial survey of five samples gave a whole body activity estimate of $43,000 \mathrm{dpm}(700 \mathrm{~Bq})$.

\section{Graduate/Undergraduate Student Involve- ment}

The USTUR Radiochemistry Program has been actively involved in the education of undergraduate and graduate students since its transfer to Washington State University. This is evident in the number of past students associated with the program, degrees granted, student publications, theses, and presentations at national and international meetings. During this project year the USTUR supported the research of Ph.D. Candidate James T. Elliston on the distribution of natural uranium in human tissues of a whole body donor to the USTUR by recovery corrected kinetic phosphorescence analysis. Dr. Elliston successfully defended his dissertation in July 2001. 


\title{
Data Management
}

\author{
Ronald E. Filipy
}

Director

\section{USTUR Case 0425}

\section{Analysis of a Whole Body Donation to the USTUR}

Analyses of tissues from a whole body donor (USTUR Case 0425) were completed during the past year. The donor had worked at a plutonium processing facility for 24 years and had a cumulative penetrating radiation dose of $0.168 \mathrm{~Sv}$. He was involved in a number of incidents with airborne plutonium, personal contamination, and minor wounds during the first decade of his employment; however, bioassays performed during his employment indicated no particular intake of actinide elements.

Case 0425 died, at the age of 83 years, from acute bronchopneumonia. He had moderate to marked atherosclerosis of the coronary arteries and a prostatic adenocarcinoma; no evidence of metastasis of that tumor was found at autopsy.

The results of the urinalyses for plutonium for Case 0425 are shown in Figure. 6; these data, along with whole body/ chest counts and incident reports, are used to establish a residence time (time between exposure and death) for purposes of radiation dosimetry. An acute intake of actinides is usually characterized by a "spike" (high plutonium content in the urine) and the time between that spike and death is the residence time. In this case, there was no clear spike in the data. The relatively high result at month 207 was coincidental with an airborne contamination incident; however, an intake was not confirmed by chest counts and there were three negative urinalysis results within the following year so the single high result is considered spurious. In the absence of a spike in the urinalysis results, the intake of actinides is assumed to have occurred over a long period of time (chronic) and a residence time is calculated by adding $67 \%$ of the time one worked with plutonium to the time between cessation of work and death (Filipy and Kathren
1996). Application of that method to USTUR Case 0425 results in a calculated residence time of approximately 35 years.

Use of the urinalysis data, as shown in Figure 6, can be somewhat deceptive. In this case, all of the results before month 181 (15y of work with plutonium) indicated no intakes; after that time, the results were more consistently positive. It is likely that this was the result of more sophisticated measurement methods. All of the measurements before month 169 were based on counting of gross alpha activity and this method may not have been sensitive enough to detect small intakes of the actinide elements.

Chest counts between months 160 and 260 did not indicate lung burdens of plutonium or americium; however, the individual had two chest counts during his last year of employment (months 289 and 290) that provided lung burden estimates of $160-190 \mathrm{~Bq}^{239} \mathrm{Pu}$ and $16-19 \mathrm{~Bq}^{241} \mathrm{Am}$. This worker was recalled for additional bioassays five years after termination of employment (month 350) and, at that time his lung burdens were estimated at $180 \mathrm{~Bq}{ }^{239} \mathrm{Pu}$ and $24 \mathrm{~Bq}$ ${ }^{241} \mathrm{Am}$. His systemic burdens were estimated to be $107 \mathrm{~Bq}{ }^{239} \mathrm{Pu}$ and $17 \mathrm{~Bq}{ }^{241} \mathrm{Am}$.

Table 3 contains a summary of plutonium and americium contents in the body organs of USTUR Case 0425 measured by radiochemical analysis. Most of the measured actinides were still in the lungs and pulmonary lymph nodes of the individual a very long time after intake. These data illustrate the accuracy with which lung burdens were estimated with the last few chest counts. The measured systemic burdens of plutonium and americium, however, were only 20-25\% of those estimated 14 years prior to death. 
UNITED STATES TRANSURANIUM AND URANIUI AEGISTRIES

PHARMACEUTICAL SCIENCES

COLLEGE OF PHARMACY

\section{Reference}

Filipy, R. E.; Kathren, R. L. Changes in soft tissue concentrations of plutonium and americium with time after human occupational exposure. Health Physics 70:153-159; 1996.
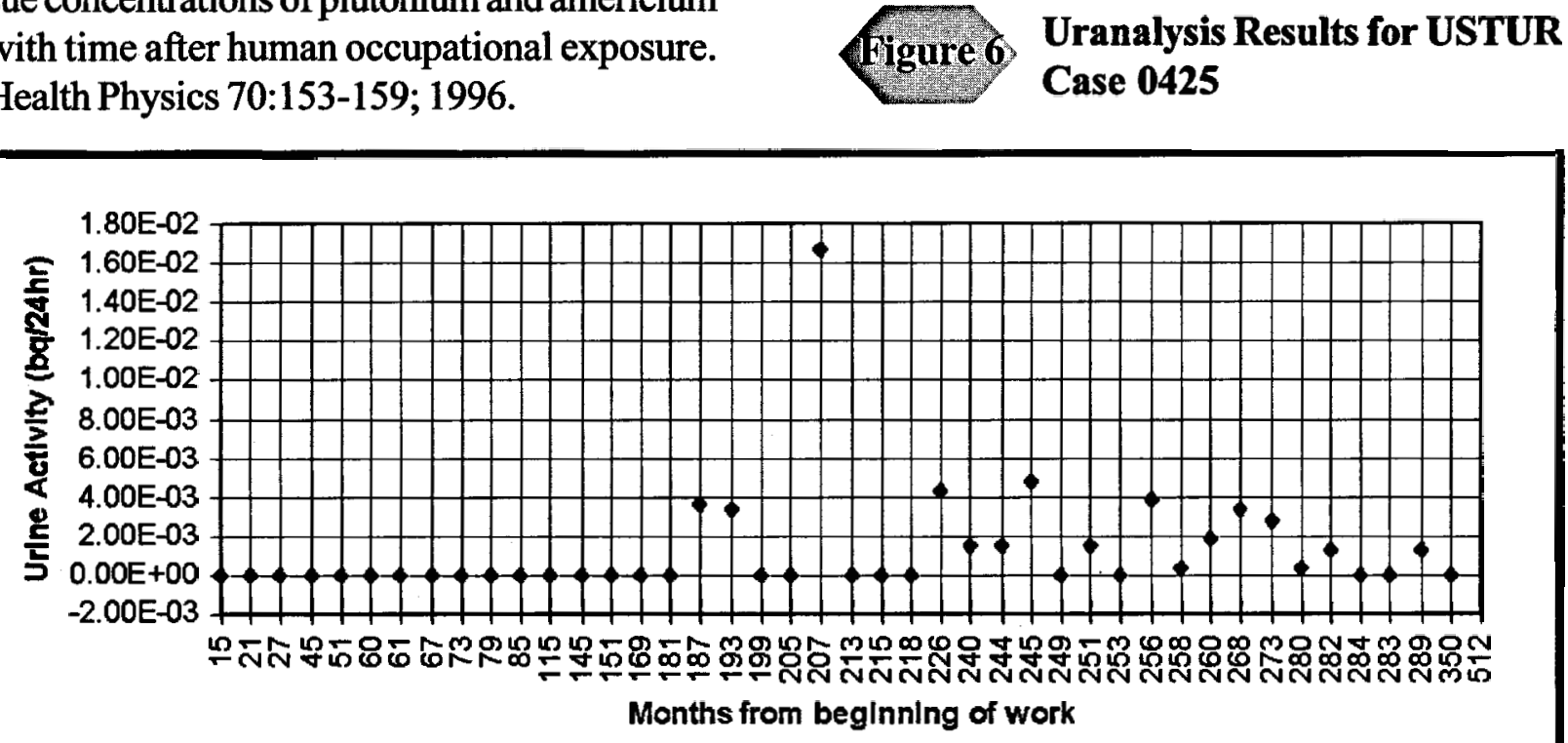

Table 3

Summary of Plutonium and Americium Contents in Body Organs of USTUR Case 0425 at Death

\begin{tabular}{|c|c|c|c|c|}
\hline Tissue/Organ & Autopsy weight (g) & ${ }^{238} \mathrm{Pu}(\mathrm{Bq})$ & ${ }^{239+240} \mathrm{Pu}(\mathrm{Bq})$ & ${ }^{241} \mathrm{Am}(\mathrm{Bq})$ \\
\hline Lungs & 1600.0 & 3.28 & 187.0 & 42.6 \\
\hline Pulmonary lymph nodes & 9.65 & 0.341 & 18.7 & 4.16 \\
\hline Liver & 1600.0 & 0.261 & 13.6 & 1.42 \\
\hline Kidneys & 235.0 & 0.0010 & 0.0275 & 0.0159 \\
\hline Spleen & 170.0 & 0.0206 & 0.978 & 0.20 \\
\hline Smooth Muscle Organs & 2185.0 & 0.0474 & 1.56 & 0.372 \\
\hline Striated Muscle ${ }^{(1)}$ & 28000.0 & 0.0636 & 1.72 & 0.671 \\
\hline Other Muscle & 550.0 & 0.00479 & 0.0363 & 0.00732 \\
\hline Skin $^{(2)}$ & 17600.0 & 0.275 & 1.40 & 0.561 \\
\hline Other soft tissue & 1670.0 & 0.0272 & 0.153 & 0.0360 \\
\hline Skeleton & 11200.0 & 0.0557 & 2.89 & 1.03 \\
\hline Systemic total & 63300.0 & 0.756 & 22.4 & 4.32 \\
\hline Whole body total & 64900.0 & 4.38 & 228.0 & 51.0 \\
\hline
\end{tabular}

(1) Reference man (ICRP-23).

(2) Includes skin and subcutaneous adipose tissue from Reference man (ICRP-23). 


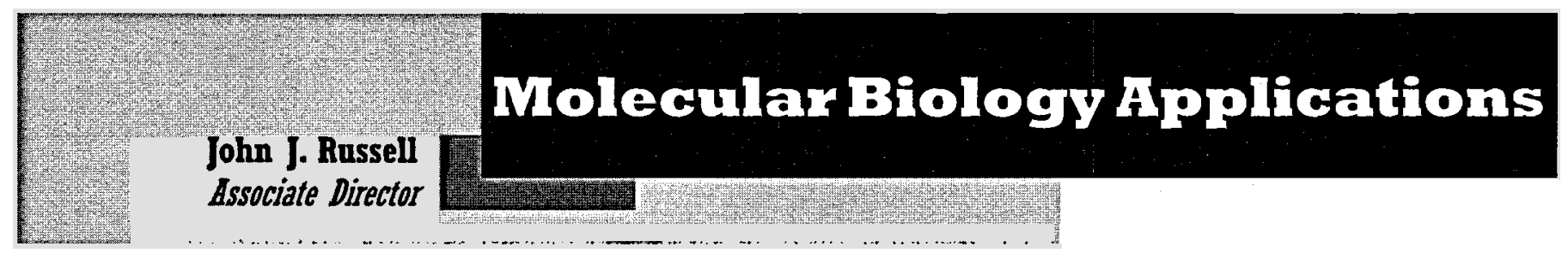

\section{Implications of Proposed Human Tissue Studies*}

Cancer in a general sense, results from the alteration in the structure or rearrangement of genes that control normal cell growth. These genetic changes usually result from damage to DNA inflicted by environmental agents / insults including radiation. Thus, a human population with well-documented exposures to carcinogens could provide useful tissue samples for studying DNA induced damage of genes involved in cancer progression. Two population groups that meet this requirement are those exposed to the actinides or radium through occupational accidental intakes or medical application. Many of the Radium Dial Painters developed bone cancer, primarily osteosarcoma or carcinoma of the paranasal and mastoid tissues. Because of the low natural incidence of these cancers, alpha particle radiation emitted by radium is ascribed to be the etiological agent. Thus, the USTUR Registrant tissues, including those of the Dial Painters and Thorotrast patients, provide an unusual resource for the study of human tumor induction because, 1) the etiological agent is known; 2) quantitative dosimetry in tissues is possible; and 3) a correlation between a damaged DNA target or gene can be correlated with actinide or radium dose and or dose rate.

\section{igure 7 Progression of the Cell-Cycle}

The Registries believe that the following ideas for study help identify important biological targets and their dose response relationship to alpha radiation-induced human carcinogenesis. These ideas for study include:

- Biological effects of alpha radiation on cell division cycle control (Figure 7).

- Determine if alpha radiation induced DNA damage is due to alteration in the DNA excision repair (ER) or mismatch repair (MMR) systems.

- Effects of alpha radiation on genomic instability

- Effects of alpha radiation on tumor suppressorgenes

*This report is part of a Professional Enrichment Program (PEP) course to be presented by J.J. Russell at the Annual Health Physics Society Meeting, June 2002 in Tampa, FL.
Cell-Cycle Defenses against DNA Damage

Checkpoints regulate the progression of the cell cycle. Both the $G^{1}$ and $G^{2}$ checkpoints are sensitive to environmental signals. i.e. nutritional needs, and will suspend or halt progression to the next cell cycle phase if DNA or a chromosomal abnormality is detected. If the DNA is damaged, the $\mathrm{G}^{1}$ checkpoint can induce cell-cycle arrest or apoptosis (cell death). Cell senescence is induced at $G^{1}$ and triggered by numerous cell divisions. The $M$ phase checkpoint is induced by faulty or abnormal chromosome segregation.

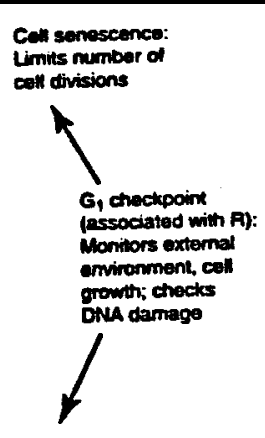

Apoptosis: Programmed cell death: self-elimination of cell from tissue

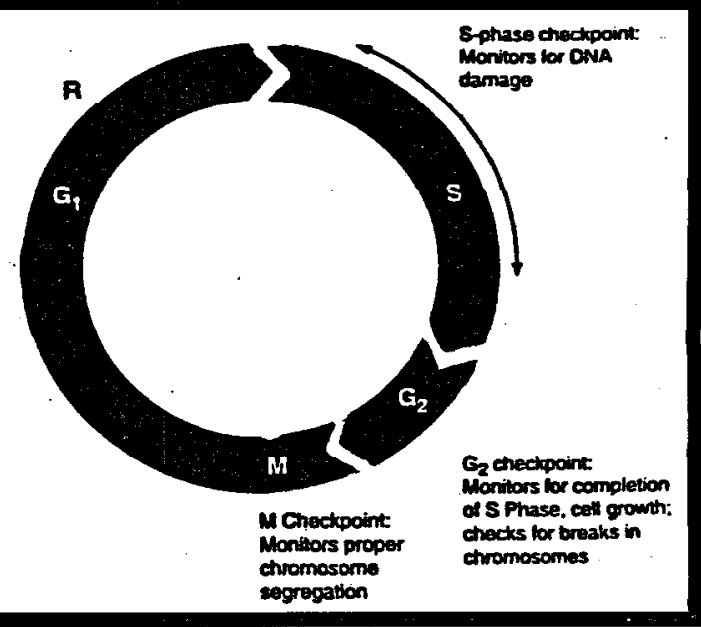




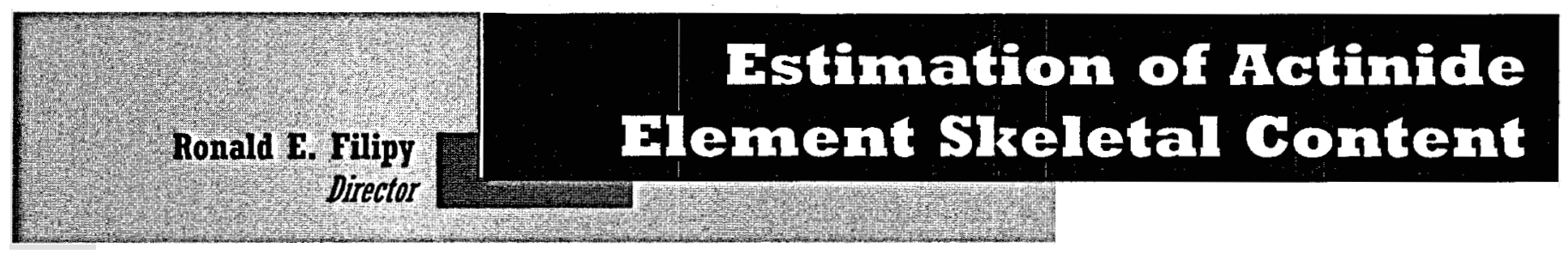

\section{Hctinide Element Concentrations}

\section{Estimation of Actinide Element Concentrations of Skeletons of Non-whole Body Donors}

The USTUR Annual Report for last year (February 1, 2000 -January 31,2001 ) contained a brief description of models used for estimation of the total skeletal content of actinide elements from the contents of the individual bones generally collected at autopsy of non-whole body donations. The models were based on the radiochemical results of eight whole body donations to the USTUR. A manuscript describing these models was accepted for publication in the scientific journal, Health Physics, and it will appear during the year 2002. The manuscript contains the data used for the development of the models as well as explanations of the prediction errors, which are not included in this report. Analyses of tissues of another whole body donation (Case 0425) were completed during the past year and the results of the skeletal analyses (not used in the model development) were used for testing the models.

The USTUR protocol for a non-whole body autopsy has specified collection of a clavicle, one or more whole ribs (excluding 1,2,11, and 12), a patella, the sternum, and a vertebral wedge (cut from within the abdominal cavity). Autopsies are usually performed by independent pathologists at the sites of Registrant deaths so there has not been complete uniformity in the number and kinds of samples received by the USTUR. The masses of samples collected in the past vary considerably. Also, the specified bone samples have changed throughout the history of the USTUR; for example, the patella was not collected in the first hundred, or so, autopsies and the vertebral wedge has been dropped from the list of specified bone samples because of a lack of uniformity in actinide contents. For these reasons, the models for estimating skeletal actinide con- tent on the basis of the bone samples collected had to be flexible enough to accommodate differing numbers and varying masses of bone samples. Actinide concentrations in the bones and skeletons were used rather than actinide contents to accommodate the mass variations of samples.

Briefly, the models were developed by performance of least squares regressions with individual bone actinide concentrations and those of the skeletons of eight whole body donations to the USTUR. This resulted in the regression coefficients for ${ }^{238} \mathrm{Pu},{ }^{239+240} \mathrm{Pu}$, and ${ }^{241} \mathrm{Am}$ (both wet and ashed weight concentrations) that are shown in Table 4. Multiplication of the coefficient and the actinide concentration in an individual bone results in an estimate of skeletal concentration of that actinide. Multiple regressions were performed to determine coefficients to use when the actinide concentrations in more than one bone are available. These regression models were developed for use with 2,3 , 4 , or 5 of the bone samples listed in Table 4. The multiple regression coefficients for use with a set of five bone concentrations are shown in Table 5. These are used by multiplication of the actinide concentration in each individual bone sample with the corresponding coefficient and summing the results for an estimate of the skeletal concentration. It is noted that some of the multiple regression coefficients are negative which is a consequence of correlation among the measured bone concentrations. This phenomenon, known as multicollinearity, occurs when two or more predictor variables (i.e., bone concentrations) are highly correlated. The correlation between all pairs of bone concentrations was greater than 0.87 for both wet and ashed samples. The existence of multicollinearity does not invalidate the estimating ability of the multiple regression equations but does increase the variability of the estimated skeletal concentration. 
UNITED STATES TRANSURANIUM AND ORANIUM AEGISTRIES

PHARMACEUTICAL SCIENCES

COLLECE OF PHARMACY

The simple linear regression and the multiple regression models for five bone samples were applied to the concentrations of plutonium and americium in five bone samples of USTUR Case 0425 and the resulting skeletal concentration estimates are shown in Table 6. Models for wet concentrations of all three measured radionuclides produced estimates of the skeletal concentrations that were in good agreement with the measured concentrations. For the plutonium isotopes, both the averages of individual bone results and the multiple regression models slightly overestimated the measured values. For americium, the average of individual bone results was a slight overestimate and the multiple regression result was an underestimate. The ash concentration model for
${ }^{239+240} \mathrm{Pu}$, likewise, provided fair estimates of the measured values; however, the multiple regression models for ash concentrations of ${ }^{238} \mathrm{Pu}$ and ${ }^{241} \mathrm{Am}$ produced substantial underestimates of the measured values. For those nuclides, the average results from individual bones provided somewhat better estimates than did the regression models. Possible reasons for the large underestimates are under investigation; although, the deficiencies of those models are not problematic in that the USTUR will be using the wet concentration models for estimation of skeletal burdens of non-whole body donations. Ashed weights were not measured when the first 100 , or so, cases were radiochemically analyzed, precluding the use of the ash concentration models.

\section{Table 4 Regression Coefficients and Goodness of Fit Diagnostics for Wet and Ashed Samples for} ${ }^{238}$ Plutonium, ${ }^{239+240}$ Plutonium, and ${ }^{241}$ Americium

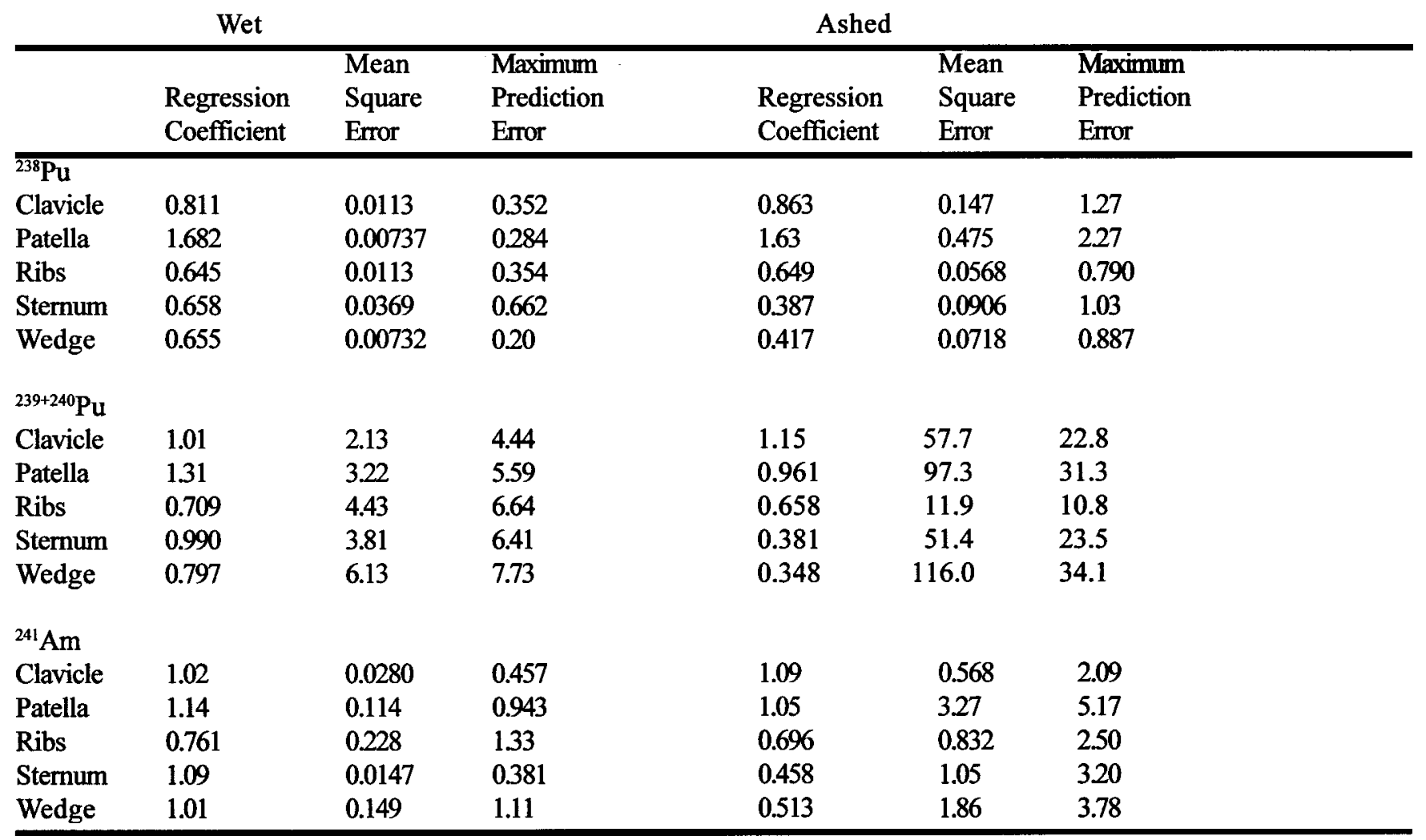


UNITED STATES TRANSURANIUM AND URANIUM REGISTRIES

PHARMACEUTICAL SCIENCES

COLLEGE OF PHARMACY

Multiple Regression Coefficients and Goodness of Fit Diagnostics for ${ }^{238} \mathrm{Pu},{ }^{239+240} \mathrm{Pu}$, and ${ }^{241} \mathrm{Am}$ Wet and Ashed Concentrations of the Five Bones Collected at Autopsy

\begin{tabular}{|c|c|c|c|c|c|c|c|}
\hline & Clavicle & - Patella & Ribs & Sternum & $\begin{array}{c}\text { Vert. } \\
\text { Wedge }\end{array}$ & $\begin{array}{l}\text { Mean } \\
\text { Square } \\
\text { Error }\end{array}$ & $\begin{array}{c}\text { Maximum } \\
\text { Error } \\
\text { Bound }\end{array}$ \\
\hline${ }^{238} \mathrm{Pu}$ (wet) & 0.368 & -0.287 & 0.744 & -0.356 & 0.0677 & 0.000980 & 0.190 \\
\hline${ }^{238} \mathrm{Pu}$ (ashed) & -0.430 & -0.723 & 1.04 & 0.0469 & 0.0941 & 0.0114 & 0.650 \\
\hline${ }^{239} \mathrm{Pu}$ (wet) & 0.614 & -0.230 & 0.298 & 0.0291 & 0.0971 & 0.293 & 3.27 \\
\hline${ }^{239} \mathrm{Pu}$ (ashed) & 0.370 & -0.158 & 0.492 & -0.0952 & 0.122 & 1.23 & 6.79 \\
\hline${ }^{241} \mathrm{Am}$ (wet) & -0.606 & 0.286 & -1.38 & 4.47 & -0.738 & 0.00136 & 0.661 \\
\hline${ }^{241}$ Am (ashed) & 1.54 & 0.870 & -1.85 & -0.572 & 1.35 & 0.427 & 11.7 \\
\hline
\end{tabular}

Application of the Bone-to-skeleton Models to Estimate the Skeletal Actinide Concentrations of USTUR Case 0425 with Comparison to the Measured Values

\begin{tabular}{clll}
\hline Bone & $\begin{array}{l}\text { Bone } \\
\text { Concentration }\end{array}$ & $\begin{array}{l}\text { Skeletal } \\
\text { Concentration }\end{array}$ & $\begin{array}{l}\text { Prediction } \\
\text { Error }\end{array}$ \\
\hline $\begin{array}{l}\text { 238Plutonium wet concentration } \\
\text { Individual bone }\end{array}$ & & \\
Clavicle & 0.0945 & 0.0766 & 0.25 \\
Patella & 0.0837 & 0.141 & 0.20 \\
Ribs & 0.111 & 0.0716 & 0.25 \\
Sternum & 0.0699 & 0.0460 & 0.47 \\
Vert. Wedge & 0.0610 & 0.040 & 0.20 \\
& & & \\
Average of individual bone results & 0.0750 & 0.19 \\
Five bones (multiple regression) & 0.0726 & \\
Measured skeletal concentration & 0.0557 & \\
\hline
\end{tabular}




\begin{tabular}{|c|c|c|c|}
\hline Bone & $\begin{array}{l}\text { Bone } \\
\text { Concentration }\end{array}$ & $\begin{array}{l}\text { Skeletal } \\
\text { Concentration }\end{array}$ & $\begin{array}{l}\text { Prediction } \\
\text { Error }\end{array}$ \\
\hline \multicolumn{4}{|c|}{$\begin{array}{l}\text { 238Plutonium ashed concentration } \\
\text { Individual bone }\end{array}$} \\
\hline Clavicle & 0.256 & 0.221 & 0.91 \\
\hline Patella & 0.317 & 0.515 & 1.6 \\
\hline Ribs & 0.326 & 0.211 & 0.56 \\
\hline Sternum & 0.376 & 0.145 & 0.74 \\
\hline Vert. Wedge & 0.253 & 0.105 & 0.63 \\
\hline \multicolumn{2}{|c|}{ Average of individual bone results } & 0.24 & \\
\hline \multicolumn{2}{|c|}{ Five bones (multiple regression) } & 0.042 & 0.65 \\
\hline \multicolumn{2}{|c|}{ Measured skeletal concentration } & 0.172 & \\
\hline \multicolumn{4}{|c|}{$239+240$ Plutonium wet concentration } \\
\hline \multicolumn{4}{|l|}{ Individual bone } \\
\hline Clavicle & 2.82 & 2.85 & 3.5 \\
\hline Patella & 1.43 & 1.87 & 4.3 \\
\hline Ribs & 4.86 & 3.45 & 5.0 \\
\hline Sternum & 3.19 & 3.16 & 4.8 \\
\hline Vert. Wedge & 4.53 & 3.61 & 5.9 \\
\hline \multicolumn{2}{|c|}{ Average of individual bone results } & 2.99 & \\
\hline \multicolumn{2}{|c|}{ Five bones (multiple regression) } & 3.38 & 3.3 \\
\hline \multicolumn{2}{|c|}{ Measured skeletal concentration } & 2.82 & \\
\hline \multicolumn{4}{|c|}{${ }^{239+240}$ Plutonium ashed concentration } \\
\hline \multicolumn{4}{|c|}{ Individual bone } \\
\hline Clavicle & 7.63 & 8.77 & 18.0 \\
\hline Patella & 5.41 & 5.19 & 23.0 \\
\hline Ribs & 14.2 & 9.34 & 8.2 \\
\hline Sternum & 17.1 & 6.53 & 18.0 \\
\hline Vert. Wedge & 18.8 & 6.54 & 26.0 \\
\hline \multicolumn{2}{|c|}{ Average of individual bone results } & 7.27 & \\
\hline \multicolumn{2}{|c|}{ Five bones (multiple regression) } & 9.63 & 6.8 \\
\hline \multicolumn{2}{|c|}{ Measured skeletal concentration } & 8.94 & \\
\hline \multicolumn{4}{|c|}{${ }^{241}$ Americium wet concentrations } \\
\hline \multicolumn{4}{|l|}{ Individual bone } \\
\hline Clavicle & 1.07 & 1.09 & 0.42 \\
\hline Patella & 0.685 & 0.781 & 0.82 \\
\hline Ribs & 1.74 & 1.31 & 1.2 \\
\hline Sternum & 1.05 & 1.14 & 0.33 \\
\hline Vert. Wedge & 1.38 & 1.39 & 0.94 \\
\hline \multicolumn{2}{|c|}{ Average of individual bone results } & 1.14 & \\
\hline \multicolumn{2}{|c|}{ Five bones (multiple regression) } & 0.818 & 0.66 \\
\hline \multicolumn{2}{|c|}{ Measured skeletal concentration } & 1.07 & \\
\hline
\end{tabular}




\begin{tabular}{clll}
\hline Bone & $\begin{array}{l}\text { Bone } \\
\text { Concentration }\end{array}$ & $\begin{array}{l}\text { Skeletal } \\
\text { Concentration }\end{array}$ & $\begin{array}{l}\text { Prediction } \\
\text { Error }\end{array}$ \\
$\begin{array}{c}{ }^{241} \text { Americium ashed concentrations } \\
\text { Individual bone }\end{array}$ & & \\
Clavicle & 2.90 & 3.16 & 1.9 \\
Patella & 2.59 & 3.72 & 4.6 \\
Ribs & 5.09 & 3.55 & 2.2 \\
Sternum & 5.62 & 2.57 & 2.7 \\
Vert. Wedge & 5.71 & 2.93 & 3.3 \\
& & 2.99 & 12.0 \\
Average of individual bone results & 1.79 & \\
Five bones (multiple regression) & 3.20 & \\
Measured skeletal concentration & &
\end{tabular}

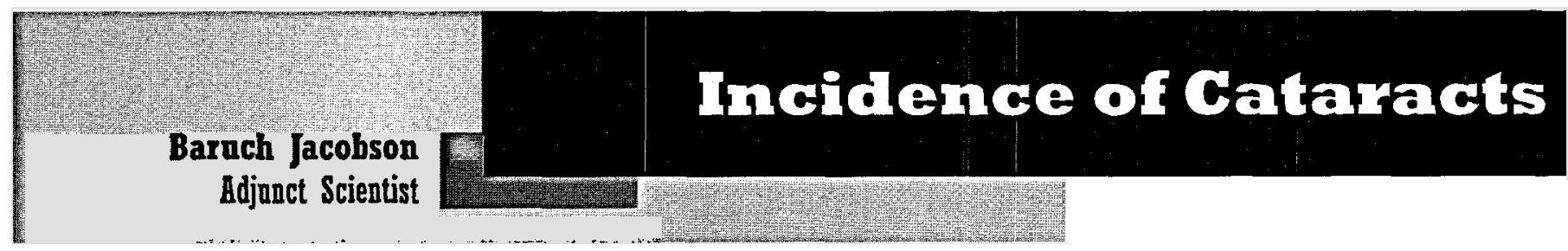

\section{Incidence of Cataracts in Registrants}

A study is underway using the medical records of USTUR Registrants from two sites to determine the incidence radiation-induced cataracts. These cataracts would be predominantly posterior subcapsular cataracts (PSC) in contrast to the common age-related cataracts, which are predominantly of the nuclear-cortical type. An excess of the PSC type cataracts would suggest a radiation effect. Patients' ophthalmologists are supplied with copies of the Registrants' signed consent forms and queried regarding the diagnosis of cataract and the type of cataract.

For the 37 Registrants with cataracts, the age at which cataracts were reported or diagnosed ranged from 63 to 85 .

\section{Table 7 Cataracts in Hanford Retirees}

For the five PSC cases, one was reported at age 82 , while the other four were reported or diagnosed at ages 65 to 69 compared with a median age of 75 for the other cataracts. The number of PSC cases was within the normal range. Lifetime external exposure records for three of the PSC cases showed exposures, either deep or shallow or both, well above average. The apparent earlier onset of PSC cases is suggestive but not statistically significant. The Registries will attempt to address the issue of precataract lenticular changes. Additional data are being obtained from Los Alamos National Laboratory Registrants; further data from other sites will also be included.

\begin{tabular}{|llccccc|}
\hline & Number & Pct. & PSC & Mixed & PSC + mixed & Other \\
\hline Reporting & 62 & & & & & \\
Cataract seen & 37 & $60 \%$ & 5 & 5 & 1 & 2 \\
No cataract & 25 & $40 \%$ & & & & $5 \%$ \\
Pct. of cataracts & & & $13.5 \%$ & $13.5 \%$ & $3 \%$ & $5 \%$ \\
\hline
\end{tabular}


John J. Russell Associate Director

\section{Wound Contamination}

\section{Report on NCRP Committee 57-17 Task Group on Wound Contamination}

The work of the National Council on Radiation Protection and Measurements (NCRP) Committee 57-17, chaired by Bryce D. Breitenstein and including J.J. Russell of the USTUR, on Radionuclide Dosimetry Models for Wounds is near competion. Much of the work over the past year involved further compilation of data (including some limited human wound case data) on the behaviour of radionuclides of wound sites, much of this coming from animal studies. The four default categories for wound retention that were agreed upon during the previous year have been modified. These are now:

- weakly retained ( $\leq 10 \%$ retained at one day, $<1 \%$ retained at 16 days);

- moderately retained (11-55\% retained at one day; $\leq 5 \%$ at 64 days);

- strongly retained (32-85\% retained at one day; $8-40 \%$ at 64 days); and

- avidly retained ( $>80 \%$ retained in one day; $>50 \%$ at 64 days).

Various forms of elements/chemical forms were allocated to these default categories on the basis of either their chemical characteristics or the results of studies in experimental animals. Thus, elements with no tendency to hydrolyse and with no affinity for tissue proteins were allocated to weekly retained elements whereas ions that could not exist at neutral $\mathrm{pH}$ and would readily hydrolyse where allocated to avidly retained elements. Examples were given of data obtained in experimental animals and model fits which generally gave good agreement.
It was necessary to provide a function for the transfer of material to lymph nodes because of the lack of specific information. The parameter value used for the human respiratory tract model was adopted and seemed to provide a good fit to available data. The model was modified from that described last year to include a compartment for colloid formation and the production of an intermediate state before either solubilisation or accumulation as aggregates or in a bound state. Particles and aggregates could either be transferred to lymph nodes or trapped in tissue.

Committee members expect that the remaining work to be done on the report document will be completed by fall 2002 and will then be forwarded to the NCRP to begin the review process.

A preliminary report of the NCRP task group's progress was presented at a recent 2002 International Commission on Radiological Protection (ICRP) meeting. The Internal Dosimetry Committee of the ICRP judged the NCRP preliminary report to be a very substantial programme of work. The guidance on the extent to which various materials could move from wound sites and the modelling approaches that were developed were very valuable and provide an important source of information for the development of the ICRP document on occupational exposure that will include transfer from wound sites. 


\section{Adwisory Committee Report}

Robert G. Thomas

Report of the Scientific Advisory Committee of the United States Department of Energy's Transuranium and Uranium Registries, operated by Washington State University on campuses at Richland and Pullman. Summary of results by members in attendance at the annual meeting, held September 21-22, 2001, at the Doubletree Inn, Pasco, Washington.

\section{Executive Summary}

The annual meeting of the United States Transuranium and Uranium Registries (USTUR) Scientific Advisory Committee was held in Pasco, Washington, on September 21 and 22,2001 . The tone of the meeting was somewhat different this year as a reflection of the 9/11 attack and two members participated via teleconferencing because of ensuing travel restrictions. They are considered as being "in attendance" for reporting purposes.

The Committee met with most of the administration and scientific staff of the USTUR; the meetings were informative, interactive, incisive and cordial. The prevalent conclusion of the members is that the USTUR is continuing to fully discharge its role and responsibility as a depository and disseminator of vital data on radiation exposure and related health effects.

During the discussion, the following specific issues were addressed.

- Case File Storage - Accumulating paper documentation of case files is causing problems of storage and ready access to the date. Since microfiche is not a viable option, other effective data-storage technology must be explored. One option is scanning records onto CD's, which could be stored separate from the hard copy files. This would facilitate retrieval of data and bring some assurance that records would be secure.
- Data Dissemination and Collaboration The balance between disclosure of information and confidentiality remains an issue. Collaborators must sign a confidentiality agreement. Unauthorized personnel must not be allowed to identify a Registrant through information from USTUR personnel, file records, or the Website.

- Rights of Deceased and Ethical Issues USTUR donor agreements were discussed in regard to contract obligations after the death of a Registrant and legal clarification has been sought on this issue. This is especially cogent in respect of confidentiality clauses in the agreement. On other aspects of this topic, a sense of caution was expressed that any work proposed by a collaborator be reviewed for possible violations of US ethical standards.

- Data Analysis and Interpretation - It is sensible for the DOE to standardize on a single software program for use in their broad information network, though the program would have to be updated periodically. Results of data analyses should address the needs of the nuclear industry to verify existing exposure guidelines or to recommend changes, which should be considered for tracking sound practices in operational safety.

- Radiochemistry Procedures Manual Should the Radiation Chemistry Procedures be distributed on the Website so that they can be viewed and downloaded by anyone? If so, they should include a disclaimer of re- 
DNITED STATES TRANSURANIOM AND URANIUM REGISTRIES

PHA RMACEUTICAL SCIENCES

COLLEGE OF PHARMACY

sponsibility for the USTUR and for Washington State University (WSU) since neither the USTUR nor WSU would have any control over use of the procedures by others.

- National Human Radiobiology Tissue Repository (NHRTR) - The collaborator studies/programs using NHRTR specimens appear both reasonable and fruitful. The molecular genetic studies of Registrant tissues may be important in identifying some of the mechanisms of radiation ionization damage to biochemical molecules. Included in the NHRTR storage facility are certain low-level environmental samples (in solution), which were analyzed long ago and it was a consensual recommendation by the Committee to discard these using acceptable methods.

- Equipment Needs - The only urgent equipment needs were additional freezer space and backup power generation for the NHRTR, and spectroscopy instrumentation for the Radiochemistry Laboratory. The new fume hood and related ductwork are currently being installed in the Radiochemistry Laboratory.

- Format of Annual Meeting - Whether the annual meetings could be accomplished through video conferencing was discussed and the Committee agreed that it was important to meet together in person, as so much of value is learned from the personal interchange. Conference telephone calls have been administratively and scientifically valuable, and these should be continued on a tri-monthly basis.

\section{Introduction}

The current USTUR program began as the U.S. Plutonium Registry in 1968 at the Hanford Atomic Product Operation in Richland, Washington. It was later merged with the Uranium Registry and operated by the Hanford Environmental Health Foundation. Since 1992, the U.S. Transuranium and Uranium Registries have been maintained by Washington State University (WSU) under a grant from the Department of Energy. As a university program, the Registries have the advantages of being integrated into an academic setting, involving other university personnel, accessing specialized analytical capabilities, and having student participation in research activities. As a Grantee, the Registries program at WSU is required to undergo regular external peer review and in addition, it is guided by the external Scientific Advisory Committee (SAC). The SAC is comprised of seven individuals with expertise in health physics, radiochemistry, medicine, radiobiology, ethics, and labor relation. This Committee meets annually to review the progress and objectives of the Registries, and this report summarized the results of their last meeting in Pasco, WA, in September 2001. The meeting brought together: 1) Directorship for the Transuranium and Uranium Registries; 2) Program Manager from the United States Department of Energy Headquarters; 3) faculty from Washington State University; 4) active researchers from the Registries scientific staffs in Richland and Pullman, WA; and 5) four members of the SAC (plus the two telephone participants) and a new member, Dennis Mahlum, Battelle Pacific Northwest Laboratories retiree. In addition, Dennis has held term appointments at the Department of Energy Headquarters and the National Academy of Sciences in Washington, DC.

The attitude throughout the meeting was cordial, business-like, and interactive. The presentations by the USTUR staff were well prepared, and the presentation handouts were very helpful in following the infor- 
mation being addressed by the speakers. The main body of this report is comprised of edited comments from the individual Committee members. These comments were assigned to the major topics discussed in the wrap-up Executive Session held on September $22^{\text {nd }}$.

\section{Committee Members}

Aldrich, Joe S.

Oak Ridge Associated Universities

Rocky Flats Environmental Technical Site

Golden, CO

Brosemer, Ronald

School of Molecular Biosciences

Washington State University

Pullman, WA

Fisenne, Isabel

Environmental Measurements Laboratory

New York, NY

(by telephone)

\section{George, Kathryn}

Department of Philosophy

College of Letters and Science

University of Idaho

Moscow, ID

Griffon, Mark

Health Physics Labor Consultant

Salem, NH

(by telephone)

Dennis Mahlum

Battelle Pacific Northwest Laboratories retiree Richland, WA
Thomas, Robert G.

Committee Chairman

Consultant

Folsom, CA

Department of Energy Representative

Brooks, Barbara

USTUR Program Manager

Office of Environment, Safety, and Health

Department of Energy

Germantown, MD

College of Pharmacy

Fassett, William (Dean)

College of Pharmacy

Quock, Ray

Department Chair

Pharmaceutical Sciences

College of Pharmacy

USTUR Faculty and Staff

Filipy, Ronald E.

Director

Russell, John J.

Associate Director

Ehrhart, Susan M.

Program Administrative Manager

Elliston, James T.

Director of Radiochemistry

Wood, Tanya G.

Scientific Assistant

Alldredge, J. Richard

Statistician 
Pham, Minh V.

Systems Analyst

Stuit, Dorothy B.

Radiochemist

Brumbaugh, Tawnya L.

Secretary

Sikov, Melvin R.

Adjunct Professor

Jacobson, Baruch

Adjunct Scientist

Birchall, Allan

Adjunct Professor

James, Anthony C.

Adjunct Professor

\section{Comments from the Executive Session}

The executive meeting was productive with all Committee members participating. Notes were taken, summarized, and versions were shortly thereafter sent to the members for their use in preparation of their individual reports. A brief list of theses topics is presented below in the form of questions, to be addressed and elaborated in major discussion sections in the main body of this report.

1. Video Meeting-should this replace our current face-to-face discussions and interactions?

2. Conference Calls - are they helpful and should they be continued?

3. Next Advisory Committee Meeting - should it include time for more one-on-one discussions at the expense of the length of the formal presentations?

4. NHRTR Laboratory - what to do with the environmental tissues analyzed by LANL and the Dial Painter Ra-226 samples now being stored in several freezers?

5. USTUR Case Files - how should back-up of case files be accomplished?

6. Dissemination and Sharing of Data-how should the program continue to alert researchers to the type of data and materials maintained at USTUR? What policies and procedures should be implemented to handle various sources and types of requests, such as from the collaborative researchers, non-collaborative researchers, family of Registrants, requests under the Freedom of Information Act (FOIA), and from the general public and lor media.

7. Policy Concerning Collaborations - what type of a policy is needed for the USTUR to examine the intent/ethics of proposed collaborative research?

8. Data Generation Priorities - should the USTUR continue giving priority to analysis of whole body cases?

9. Radiation Chemistry Procedures Manual-how should these procedures be disseminated to other radiochemists and their laboratories?

10. Data Analysis - how should the Registrant and the Russian data be compared and presented?

11. Causes of Registrants Death - what is the most 
reliable source of cause-of-death data and could these be compiled into a listing for publication?

12. Medical History/Work History-is it possible to get any health end points out of the database information?

\section{Condensed Comments from Committee Members' Reports}

\section{General Comments}

The DOE has received the USTUR application for renewal of their three-year grant, with funding to be in annual increments. The results of DOE's peer review of the application is expected before January 2002. Funding is likely to be flat, i.e., not increased. The new Secretary of Energy is in place and the administration is trying to make new appointments. Open positions make it difficult to move ahead as does the continuing budget resolution. It is important that both the USTUR and the Scientific Advisory Committee understand what DOE's Office of Health Programs needs, to show the value of USTUR research not only to DOE but for all organizations devoted to the study of occupational exposure cases, radiation dosimetry, and health effects.

It was also noted that the Office of Health Programs is working to develop an agenda of health research topics that would complement its program of health services. USTUR might consider expanding research related to three of the topics on the agenda, which is still in draft. The topics are: 1) understanding health effects of internal radiation by comparing estimates of doses based on USTUR radioanalyses of tissues with doses calculated from bioassay and in vivo measurements; 2) study of cellular/molecular mechanisms to identify biomarkers of radiation exposure and occupational diseases; 3 ) investigation of the patterns of accruement of external occupational dose.
The Committee discussed recommendations on the format of the next annual meeting. Presentations should be shortened in some cases. Perhaps two hours could be set aside for special interests with break-out sessions and shorter scientific presentations that permit more one-on-one interaction. The suggestion of setting aside a half-day for workshoptype interactions between the USTUR staff and Advisory Committee members is strongly endorsed. The length and number of presentations would need to be reduced to accommodate the usual two-day schedule. Perhaps more than two hours is needed for the first time around to just see how they go. It might take the form of breakout sessions on major topics and Committee members could join one or more of them depending on interests. Two days are still appropriate for the meeting at a similar time of year.

Also, it would be helpful to have a CD-ROM containing presentations and other materials sent to the Committee in advance of the meeting. This would eliminate the paper copies and binder. Then the reviewers need only make notes as the PowerPoint presentations are made and download any specific items at a later time.

It was agreed that the quarterly conference calls should continue as they have been productive in bringing potential issues to the Committee in a timely manner. The next one will be scheduled for December this year, before this report is finalized.

The cost per radiochemical analysis should be carefully scrutinized by the USTUR as it will assist in determining the estimates for Work For Others (WFO). The cost should be clearly defined as the cost of the radioanalytical or stable element analyses themselves. Clerical and administrative costs should be considered separately as these are somewhat of a moving 
UNITED STATES TAANSURANIUM AND URANIUM REGISTRIES

PHARMACEUTICAL SCIENCES

COLLEGE OF PHARMACY

target that may vary with time. This information could be obtained by having the radiochemists keep track of how many hours it takes for a whole body analysis or a simpler tissue analysis but it may not be worth the effort and the record-keeping time.

The development of a public use database was discussed, although such a database involves difficult issues of confidentiality. Such a database would be available and useful for teaching at the graduate or undergraduate level.

A labor representative cognizant of radiation risk should be elected as a replacement on the Committee. One suggestion for obtaining such a representative is to call the union at Battelle PNNL for a nominee. Some Committee members have not ever been able to attend the annual meeting so new members should be apprised of their duty to attend these meetings and be asked not to accept the appointment unless they commit to attend except under the most extraordinary of circumstances (this year did present extraordinary circumstances for some people, given the $9 / 11$ event). A recommendation from last year's Committee meeting suggested that a survey be conducted through the Health Physics Society concerning the value of the USTUR to operational practices in the nuclear industry. This was withdrawn.

\section{Case File Storage}

Accumulating paper documentation of case files is causing problems of storage and ready access to the data. Since microfiche is not a viable option, other effective data-storage technology must be explored. The Committee agreed that back-up copies of case files are needed and recommends that USTUR staff investigate options and costs. One option is scanning records onto CD's, which could be stored separate from the hard copy files. It would facilitate retrieval of data and bring some assurance that records would not be lost. Scan- ning of records is a good idea for space consolidation but can the scanning allow searches on individual items within any given sheet of scanned-in data or only on sheets pertaining to an individual? If queries can be developed on specific cells or sets of data then meaningful queries can be established. If the queries can only be set up for individual sheets, one has to manually extract tidbits of information to develop meaningful data sets. The scanning to some form of electronically compatible media will also make it easier to work with the information in various databases. The question of whether the paper document should be kept as back-up was not settled. The costs will be investigated. Some thought it to be vital that the original paper records be kept in fireproof file cabinets or a similar protective area.

\section{Data and Dissemination Collaboration}

There is international interest and support of the UK's National Radiation Protection Board (NRPB) in collaborating with USTUR on a project that may lead to DOE's standardizing on a single software program for use in their broad information network. The software (called INMA - Integrated Modules for Bioassay Analysis) being customized for DOE sites to use in calculating internal occupational doses seems ideal. It recognizes the value of linking the analysis data from the USTUR cases to model verification. The inclusion of the IMBA group broadens the potential applications of this software package. However, the question arose about who within the Registries are involved in the decision process to collaborate with another institution.

The balance between disclosure of information and confidentiality remains an issue. Last year's report to the USTUR suggested that they "consider issues involved and develop options which can be discussed with the Committee". This should be addressed prior to the $\mathrm{Au}$ gust 2002 Committee meeting. It would also be a 
good time to coordinate these issues with the Comprehensive Epidemiological Data Resource (CEDR). It is necessary to either review and modify existing procedures regarding the release of information or to develop specific policies regarding this topic.

Some of the discussions on this topic addressed the need of the Registries to alert researchers to the type of data and materials maintained at USTUR. This information could be available on the Web to anyone. It could be a promotional/teaser set of general information, to give an idea of what the USTUR has, and could invite those wanting more information to contact the Director. However, there are difficulties in maintaining the confidentiality of subjects; standard procedures may not prevent an informed person from identifying the subject. Restrictive procedures that limit use of the data may be necessary.

Policies and procedures need to be developed or clarified to handle various sources/types of requests, such as the following: collaborative researcher; noncollaborative researcher; family; requests under Freedom of Information Act(FOIA); general public/media. This may require a decision on what constitutes de-identified data for USTUR purposes; this may be slightly different for dead vs. living Registrants and may result in limited data available through the CEDR.

How much information about the project should be placed on the Web? The consensus was that collaborators should sign a confidentiality agreement (which they already do) and that general information only should appear on the Website to get collaborators' interest. A policy needs to be developed concerning release of information to inquirers and how to make an official request for information. It might be sensible to put radioanalytic results on the Web without detailed information that permits deducing whom the person was.

The number of hits on the Website home page is com- pelling evidence of the utility of this outreach tool. It also emphasizes the need for constant update so it does not become another cobweb.

\section{Rights of Deceased and Ethical Issues}

USTUR donor agreements were discussed in regard to contract obligations after the death of a Registrant and legal clarification has been sought on this issue. This is especially cogent in respect to confidentiality clauses in the agreement. On the question of the rights of confidentiality, it was suggested that the deceased lose many of their rights. That is quite true, but usually so because they are no longer able to exercise their rights and can be harmed only in a limited number of ways. The deceased have rights to have a will executed as they have intended in their lifetime. Wills are not incontestable, but the parties who wish to contest them must show that the person was not competent at the time of making the will or was forced to make the will against her/ his choice or something similar. Such a will may contain a confidentiality clause, say, with regard to a gift to a charity. Perhaps thinking about the USTUR donor agreement as a will with a confidentiality clause will help the Committee in considering how to deal with participant confidentiality.

Summarizing a Registrant's medical history in the comments section of the database is acceptable and it would be advantageous to be alert to information in either the work or medical histories provided by the Registrant that could be used to cross-check various parameters. Cause of death will always be rather precarious with too much subjectivity. Autopsy data help in some cases, but often, the cause of death is given by a family physician without a detailed examination of the body. Occupation and consistent work location can be helpful for those who have not relocated frequently. Identification of a participant's occupation and work location actually is a part of the Web-teaser as it is associated 
UN ITED STATES TRANSURANIUM AND URANIUM RECISTRIES PHARMA CEUTICAL SCIENCES

with the teaser data for differing participants from different facilities. Persons who have worked and have been potentially exposed at more than one DOE weapons complex add further complexity in ascertaining a true exposure picture. Very few people stayed in the same job capacity throughout their work history even if they worked at the same facility.

A sense of caution was expressed that any work proposed by a collaborator be reviewed for possible violations of U.S. ethical standards. Agreements between collaborators and USTUR should specify in writing what restrictions apply and how differences between parties will be handled. Such outside collaborations can greatly enhance the use of the information developed by the USTUR. With all of the resources invested in USTUR, it is imperative to get as much return as possible. There may be a need to form a policy for the USTUR to examine the intent/ethics of proposed collaborative research. Dr. George did a complete review of the Policies and Procedures manual, with special attention to ethical and possible legal concerns, last year. It should be a comprehensive document applicable to all aspects of the work performed by the USTUR.

A discussion arose about collaborating with the group in the UK and whether this caused ethical concem. USTUR scientists must take care not to be collaborators on projects where scientists (probably in other countries) may be doing research that is illegal, or ethically questionable, in the U.S. Scientists seeking to share information and tissues gathered by the Registries should agree to co-author papers with USTUR scientists.

\section{Data Analysis and Interpretation}

There was a time when negative data from epidemiological research were looked upon as being useful with regard to a given effect on the public health. The tendency today is to ignore negative data and extrapolate all existing data $a$ priori back to a zero health effect only at zero dose, in order to derive risk factors for even subthreshold dosages and attest "uncertainties" in how the data were obtained and presented. It may be cogent in this regard for the USTUR data showing no health effects to be expressed through a comparison with the Russian data, to probe for any relationship between human health effects and low radiation doses. An attempt may also be worthwhile to graphically present the fractional tissue distribution of the amount of Pu or other transuranics in Registrants and in Russian workers, to see how the amount in a single case compares to others. Analysis of data should begin with determining whether the values follow a normal or a log-normal distribution. Most risk analyses start with calculation of an arithmetic mean with no prior determination of the nature of the numerical distribution. Using an arithmetic mean on a log-normallydistributed set of data will most often make the doseeffect appear greater. The misuse of "uncertainty" has the same end result.

A definitive statement was made that no adverse effects were found in the Russian cohort at estimated body burdens of $\angle 200 \mathrm{nCi}$ of ${ }^{239} \mathrm{Pu}$. This could be interpreted to mean that the USTUR should only seek donors with body burdens in excess of this value, but the mission of the Registries is not to pursue adverse effects but to assist in developing verifiable radiation protection standards.

In the USTUR working database table it was suggested that the header "Residence Time" either be annotated or changed to "Time from Exposure to Death".

One broader suggestion with regard to analysis of the USTUR data was aimed at the practical operational aspects of health protection in the nuclear industry. Currently, the numerical product of the Registries is a body burden for a particular radionuclide or mixture 
of radionuclides, determined by adding the amount of the radionuclide(s) within all of the body organs of an individual. In the nuclear industry the operating health physicist monitors the workplace by taking air and other samples during working hours, assuming that the air concentration he/she operates below is safe for the worker. This air sampler guideline may include many orders of magnitude factors of safety. The suggestion made at the meeting was to utilize the Registries' whole body and organ data and mathematically analyze them in reverse through the International Commission on Radiological Protection (ICRP) lung model to derive such air concentration guidelines. By applying these data in a reverse sense through the inhalation process, a data-based air concentration guideline should be derivable. Any acceptable organ dose upon which to base the derived air concentration must recognize that the time-damage dose to an organ is much less for a given long-term radionuclide than for a single whole body exposure.

\section{Radiochemistry Procedures Manual}

Should the Radiation Chemistry Procedures be distributed on the Web so that they can be viewed and downloaded by anyone? If so they should include a disclaimer of responsibility for the USTUR and WSU. If not placed on the Web, should a version be made otherwise available? If so, then the question arose about whether to charge a fee for copies of the Radiochemistry Procedure Manual. Three requests were received last month. So the question facing the USTUR and WSU is: should it be on the Web? Should it be free? A government laboratory has made such procedures available on the Web and on $\mathrm{CD}$, which is cheaper than paper copies and cuts costs for mailing. No decision by the SAC was forthcoming on this matter.

The Radiochemistry group has been very productive despite perennial problems with fume hoods and the recent loss of one full time chemist. The principal con- cern is a replacement chemist; Dr. Elliston assured the Committee that interviews are in progress.

The anticipated needs for laboratory equipment, upgrades of the alpha spectrometry, software and hardware are reasonable and necessary.

The use of fluoride resulted in low yields on several samples. Unless there is clear information or indication that the soft tissue or bone could contain mineral acid insoluble material, that is refractory Pu or Am, the use of fluoride, either as FIF or KF fusion, should be avoided. In any analysis the fewer reagents required to perform the separation the less likely it is to encounter problems.

The ascorbic acid reagent problem can be resolved by stating on the purchase order "NO SUBSTITUTION". Both the ascorbic acid and the indicator dye should be ordered on an annual basis. The reagent bottles should be dated with the date of receipt.

The ashing experiment in the stainless steel cans was not successful. Whether this was due to the use of vented lids is not known. The bone ashing at DOE's Environmental Measurements Laboratory was always performed in open silica or stainless steel trays. The oven was started at room temperature and the samples dried at $110^{\circ} \mathrm{C}$ overnight. The oven temperature was increased in $50^{\circ} \mathrm{C}$ increment's with ashing overnight until $300^{\circ} \mathrm{C}$ was attained. From there to $500^{\circ} \mathrm{C}$ the increments were $100^{\circ} \mathrm{C}$. The final temperature was $550^{\circ} \mathrm{C}$ with ash time over the weekend. The bone samples were broken open with a pestle and ashed for an additional 24 hours.

It is agreed that the use of NIST materials is prohibitively expensive and not likely to be effective as a Quality Assurance sample because of the huge uncertainties associated with the certificate value. The development of in-house materials is wise. The values can and 
should be verified by an independent method and possibly another laboratory.

No further measurement of environmental levels of uranium should be supported.

The choice of USTUR Case 0259 is troubling as it was an inhalation exposure to ${ }^{238} \mathrm{PuO}_{2}$ ceramic particles. This should be a refractory material, which would require some form of fluoride dissolution. The actual chemistry performed at LANL was not feasible and it is very important that the validity of the radiochemical results is made clear by a brief description of the chemical methodology.

National Human Radiobiology Tissue Repository After discussions revealed that the solutions resulting from LANL's analyses of environmental-level tissues were unlikely to be useful for additional research, the Committee recommended that they be discarded. This would free up valuable space needed by USTUR. The legacy inherited by the Registries from LANL has and will require considerable staff effort to inventory and sort the materials, even though significant headway has been made in this task area. The staff wished to know what to do with 2-300 boxes of environmental samples, all of which have values listed on the boxes. WSU Environmental Health and Safety can dispose of these in the proper way and it was agreed that this was to be done.

In view of the advanced age of many Registrants and the anticipated increase in whole bodies to analyze, USTUR needs to have additional freezer space. Considerations should be given to immediate purchase or to freeing up space in current freezers. In this regard, the issue of continuing to store all of the ${ }^{226} \mathrm{Ra}$ samples should be discussed. The freezers would be available as back-up in case of equipment failure. There was discussion of seek- ing funding for one new $20 \mathrm{ft}$ ' freezer a year as well as funding for backup generators.

The collaborator studies/programs using NHRTR Specimens appear both reasonable and fruitful. However, it is disappointing that the collaboration with Texas A \& M failed. The instrument selected for the measurement of Pu, PERALS, was not appropriate. This could have been avoided had the detection limit of the PERALS system been calculated prior to committing to its use.

The molecular genetic studies of Registrant tissues are important in identifying the mechanisms of radiation ionization damage to biochemical molecules. The tissue microarray analysis of NHRTR tissues is a good exploratory project.

\section{Format of Annual Meeting}

The question arose about whether the meetings could be accomplished through video conferencing. Committee members agreed that it was important to meet together in person at least once per year, and that so much of value is learned from the in-person interchange. They agreed that the meetings should continue as they are and that video meetings should substitute for the in-person sessions only in the case of an emergency. All but one Committee member agreed that in light of recent uncertainties in travel conditions, it might be well to set up a short midyear meeting using video, something like a half-day meeting to see how difficult it is to get everyone on board and determine if there can be a meaningful interchange. That would at least provide real information about the effectiveness, both cost and information exchange, of such an effort. While the Committee recognizes the costs associated with the annual meeting at WSU, the benefits of face-to-face discussions and interactions outweigh them.

\section{Additional Member Comments}

It was a good meeting by a well-prepared staff. I also like the way the staff were all involved and seemed to participate in a number of different aspects of the pro- 


\section{ONITED STATES TRANSURANIOM ATD DAANIOM AEGISTRIES}

PHA MACEOTCHL SUENCES COLLEGE OF PHARMACT

gram rather than each being confined to a narrow job description. For a small operation, it is imperative that each member has a good feel for the overall scope of the project. The presentations by all the participants were thorough and well done. PowerPoint slides and handouts were very useful for the Committee members in understanding the work that has been done over the last year. Also, compliments to the staff on the Annual Report and other communications. The Annual Report was well done in a manner that made reading easy and yet conveyed the essential information. The Newsletter looked very good. The Quarterly Reports are more informative concerning day-to-day activities. The Website is looking very good and is user friendly.

The USTUR staff in both locations are recommended for stepping up to the plate, digging in and rectifying several situations that we as a Committee felt needed to be accomplished such that the USTUR presents a more involved, organized, and polished organization. Also, it appears that John Russell and other staff are fielding inquires from the public and the media very well.
Ray Quock's presentation on the radiopharmacy degree was really interesting and the Committee wonders if it would not be a good thing to encourage WSU's Chemistry Department to offer a special degree in radiochemistry to tie in with this (if they don't already do so). We think WSU should do some widespread recruiting on this.

The conference organizer, Susan Ehrhart, again did an excellent job of arranging the meeting and making up a very useful packet for all of us. Special thanks to her. And thanks to the Filipys for a delightful evening as it provided a very appropriate opportunity for the Committee members and project scientists and staff to interact in an informal setting.

\section{Appreciation}

The Chairman wishes to acknowledge the important and extensive editorial input to this report provided by Committee member Ron Brosemer.

\section{Advisory Committee Meeting Agenda}

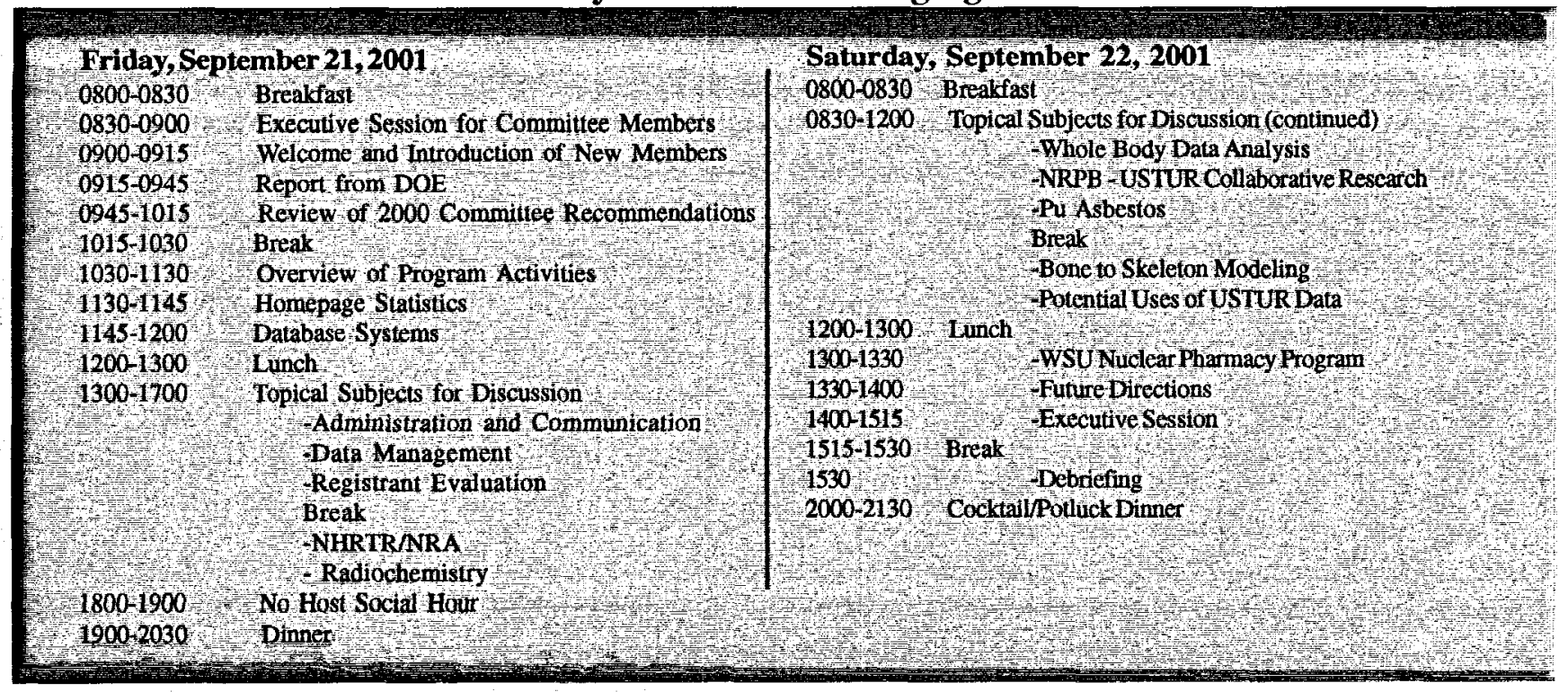




\section{Publioations and Presentations}

Susan M. Ehrhart

Program Administrative Manager

\section{Publications of the USTUR}

The following manuscripts and presentations were published, submitted for publication, presented or in progress for the period February 1,2001 to January 31,2002 . Previous manuscripts and abstracts are available on the USTUR website at www.ustur.wsu.edu.

Abstracts of open peer-reviewed published manuscripts are included in Appendix A of this report.

\section{Published}

Brooks, A.L., S. Bao, K. Rithidech, L.A. Couch and L.A. Braby. Relative Effectiveness of HZE Ion-56 Particles for the Induction of Cytogenetic Damage In Vivo. Rad. Research 155:353-359; 2001.

Ehrhart, S.M. and R.E. Filipy: Facts About the United States Transuranium and Uranium Registries. Color Brochure. USTUR-0173-01;2001. College ofPharmacy, Washington State University, Richland, WA.

Ehrhart, S.M. and R.E. Filipy. United States Transuranium and Uranium Registries Annual Registrant Newsletter. Issue \#8. USTUR-0179-01; 2001. College of Pharmacy, Washington State University, Richland, WA.

Ehrhart, S.M. and R.E. Filipy. United States Transuranium and Uranium Registries Amulal Report: February 1,2000 - January 31,2001 .USTUR-017701;2001. College of Pharmacy, Washington State University Richland, WA.

rat)

numbentipy

stats Many of ho

Elliston, J.T., S.E. Glover and R.H.Filby: The Determination of Natural Uranium in Human Tissues by
Recovery Corrected Kinetic Phosphorence Analysis. J. of Radioanalytical and Nuclear Chemistry $248(2): 487-$ $491 ; 2001$.

Russell, J.J. Interstitial Lung Disease of Occupational Origin:ACase Report. (Abstract)Health Phys. 80:S111; 2001.

Russell, J.J. and R.L. Kathren. Uranium Deposition and Retention in a USTUR Whole Body Case. (Abstract) Health Phys. 82(6):S165; 2002.

Sikov, M.R. and J.J. Russell. Fetoplacental Dosimetry of Plutonium Burdens Incurred Prior to Pregnancy. (Abstract) Health Phys. 80:S123; 2001.

Wilson, W.E., D.J. Lynch, K. Wei and L.A. Braby. Microdosimetry of a $25 \mathrm{KeV}$ Electron Microbeam. Rad. Resqarch 155:89-94; 2001.

\section{Submitted}

Filipy, R.E., R. Alldredge, C. Hall, J. McInroy, S. Glover, and S. Qualls. Estimation of Actinide Skeletal Content in Humans Based on Bone Samples Collected at Autopsy. Health Phys.

James, A.C., R.E. Filipy, J.J. Russell and J.F. McInroy. USTUR Case 0259 Whole Body Donation: A Comprehensive Test of the Current ICRPModels for the Behavior of Inhaled ${ }^{238} \mathrm{PuO}_{2}$ Ceramic Particles. Health Phys.

Russell, J.J., M.R. Sikov, and R.L. Káthren. Plutónium Content Of Human Placental Tissues Twelve Years After Occupational Exposure Radiat. Prot Dosim ot dor (a) $=0$

$$
\text { kera }
$$

Russell, J.J. Human Wound Site Tissue Contaminated with Actinide Material. (Ábstract) Health Phys 
Russell, J.J. Implications of Proposed Future Human Tissue Studies of the USTUR. (Professional Enrichment Program course to be presented at the Annual Health Physics Society Meeting, July 2002 in Tampa, FL.) Health Phys.

\section{In Preperation}

Elliston, J.T. and R.H. Filby. Comparing the Determination of Natural Uranium in Human tissues by Traditional Kinetic Phosphorescence Analysis Versus Recovery Corrected Kinetic Phosphorescence Analysis.

Glover, S.E., J.T. Elliston, G. Deckert, D.B. Stuit, R.H. Filby and R.E. Filipy. Bone Calcium Content as a Predictor of the Contents of Actinide Elements in the Human Skeleton.

\section{Presented}

June 2001

Filipy, R.E. presented a poster presentation entitled "Collaborative Researchers Wanted by the USTUR" at the $46^{\text {th }}$ Annual Health Physics Society meeting in Cleveland, Ohio. This poster presentation was also presented again during June for the WSU Cancer Prevention and Research Center retreat, in Coeur d Alene, ID.

Russell, J.J. presented an oral presentation entitled "Interstitial Lung Disease of Occupational Origin: A Case Report" at the $46^{\text {th }}$ Annual Health Physics Society meeting in Cleveland, $\mathrm{OH}$.

Sikov, M.R. presented an oral presentation entitled "Fetoplacental Dosimetry of Plutonium Burdens Incurred Prior to Pregnancy" at the $46^{\text {th }}$ Annual Health Physics Society meeting in Cleveland, $\mathrm{OH}$.

July 2001

Elliston, James T. successfully defended his Ph.D dissertation on "The Distribution of Natural Uranium in Human Tissues of a Whole Body Donor to the USTUR by Recovery Corrected Kinetic Phosphorescence Analysis" at Washington State University, Pullman, WA. 


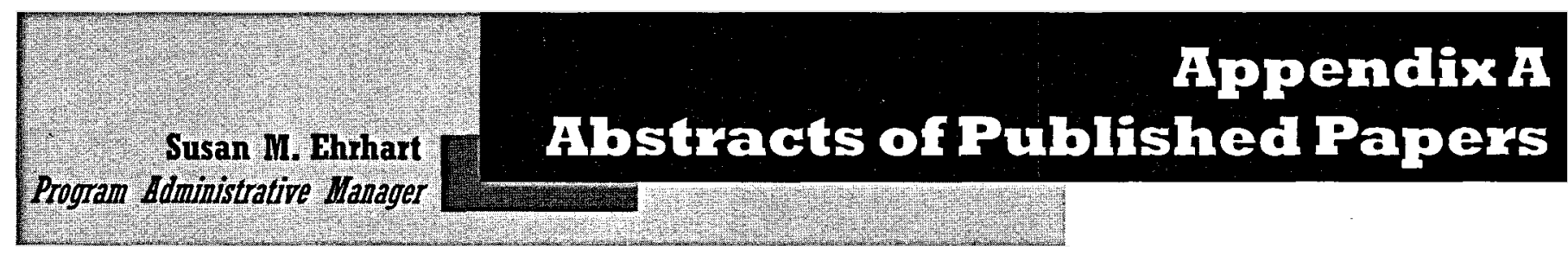

\title{
Alstracts
}

\section{USTUR-0157-00}

\section{Relative Effectiveness of HZE ${ }^{56}$ Fe Particles for the Induction of Cytogenetic Damage in Vivo}

\author{
Antone L. Brooks, Shiping Bao, Kanokporn Rithidech, Lezlie A. Couch, Leslie A. Braby \\ Washington State University-Tricities, Richland, Washington 99352
}

Risk from prolonged manned space flight includes the radiation exposure from galactic cosmic rays containing high energy, heavy ions like ${ }^{56} \mathrm{Fe}$. Studies were conducted at the Brookhaven National Laboratory by exposing Wistar rats to high mass, high-energy (HZE) particles using the Alternating Gradient Synchrotron (AGS). The biological effectiveness of ${ }^{56} \mathrm{Fe}$ ions (1000 GeV/AMU) relative to low-LET gamma rays and high LET alpha particles for the induction of chromosome damage and micronuclei was determined. The mitotic index and the frequency of chromosome aberrations were evaluated in the bone marrow and the frequency of micronuclei was measured in cells isolated from the trachea and the deep lung. A marked mitotic lag was induced in the bone marrow, which decreased as a function of time after the exposure. The frequency of chromatid aberrations and micronuclei increased as a linear function of radiation dose. Aberration frequency induced by HZE particles was about 3.2 times higher than that observed following exposure to ${ }^{60} \mathrm{Co}$ gamma rays. The frequency of micronuclei in rat lung fibroblast, lung epithelial cells and tracheal epithelial cells increases linearly with slopes of $7 \times 10^{-4}, 12 \times 10^{-4}$ and $11 \times 10^{-4}$ micronuclei/binucleated cell/Gy, respectively. When genetic damage from ${ }^{56} \mathrm{Fe}$ was compared to that from exposure to ${ }^{60} \mathrm{Co}$, ${ }^{56} \mathrm{Fe}$ was between 0.9 and 3.3 times as effective as ${ }^{60} \mathrm{Co}$. However, the HZE exposures were less effective than radon $(0.1$ to 0.2$)$ in producing micronuclei in either deep lung or tracheal epithelial cells. Studies using micro-dosimetric techniques estimated that there were about 60 cells hit by delta rays for each cell that was traversed by the primary $\mathrm{HZE}{ }^{56} \mathrm{Fe}$ particle. These calculations and the observed, low relative effectiveness of the radiation exposure to HZE particles suggest that at least part of the cytogenetic damage measured was caused by the delta rays. Much of the energy deposited by the primary HZE particles may result in cell killing and therefore be "wasted" as far as production of detectable micronuclei is concerned. The role of "wasted" energy on cancer induction may be very important in risk estimates for HZE particles.

Published in Radiation Research Vol. 155:353-359; 2001. 
UNITED STATES TRANSURANIUM AND URANIUM REGISTRIES PHARHACEUTICAL SCIENCES

COLLEGE OF PHARMACY

\title{
USTUR-0168-00
}

\section{The Determination of Natural Uranium in Human Tissues by Recovery Corrected Kinetic Phosphorescence Analysis}

\author{
J. T. Elliston ${ }^{1}$, S. E. Glover ${ }^{2}$, and R. H. Filby ${ }^{3}$
}

${ }^{1}$ United States Transuranium and Uranium Registries, Nuclear Radiation Center, Washington State University, P. O. Box 641300, Pullman, WA 99164-1300, USA; ${ }^{2}$ Department of Environmental and Occupational Health, 260 Kappa Dr., University of Pittsburgh, Pittsburgh, PA 15238, USA; ${ }^{3}$ Department of Chemistry, Washington State University, P.O. Box 644630, Pullman, WA 99164-4630, USA.

Two typical methods used for the determination of uranium in human autopsy tissues are kinetic phosphorescence analysis (KPA) and alpha spectrometry, both of which have significant limitations and advantages. KPA is limited because of the amount of sample used (1-10 mL for sample digestion followed by one $\mathrm{mL} \mathrm{KPA}$ aliquots), no isotopic information is provided, phosphorescence degradation by salts in solution, and even more importantly, it does not provide chemical recovery information. For example with sub ng uranium concentrations per $g$ of inorganic material, preconcentration is necessary, which may require chemical recovery (other than simple evaporation). While alpha spectrometry has very good radiometric detection limits for ${ }^{238} \mathrm{U}$, the very long half-life of ${ }^{238} \mathrm{U}\left(4.468 \times 10^{9} \mathrm{y}\right)$ restricts its mass detection limit (27 ng). KPA, on the other hand, has a detection limit three orders of magnitude lower $(0.02 \mathrm{ng})$ for natural uranium. A recovery corrected method for the determination of natural uranium in human tissues was developed combining preconcentration of human tissues dissolved in $6 \mathrm{M} \mathrm{HCI}$ by anion exchange with alpha spectrometry and kinetic phosphorescence analysis, utilizing ${ }^{232} \mathrm{U}$ as a tracer. Solution aliquots containing up to $6 \mathrm{~g}$ of bone ash were pre-concentrated for KPA measurement thereby allowing the use of up to $25 \%$ of the original sample solution weight for analysis by KPA. The radiochemical yield of ${ }^{232} U$ was determined by alpha spectrometry and the uranium content was determined by KPA. The mean radiochemical yields obtained for human tissue samples range from $65 \%$ to $106 \%$ with a mean of $85 \% \pm 8 \%$.

Published in the Journal of Radioanalytical and Nuclear Chemistry Vol. 248(2):487-491; 2001.

\section{USTUR-0171-01}

\section{Microdosimetry of a $25 \mathrm{keV}$ Electron Microbeam}

\author{
W. E. Wilson', D. J. Lynch ${ }^{1}$, K. Wei1, and L. A. Braby ${ }^{2}$
}

${ }^{1}$ Washington State University Tri-cities, Richland, WA 99352; ${ }^{2}$ Texas A\&M University, College Station, TX 778843 


\title{
UNITED STATES TRANSURANIUM AND URAHIUM REGISTRIES \\ PHARMACEUTICAL SCIENCES \\ COLLEGE OF PHARMACY
}

Electron microbeam experiments are planned or under way to explore in part the question regarding whether the bystander effect is a general phenomenon or is restricted to high-LET radiation. Since low-LET radiations scatter more readily compared to high-LET radiations, identifying bystander cells and assessing the potential dose that they may receive will be crucial to the interpretation of radiobiological results. This paper reports on initial calculations of the basic information needed for a stochastic model of the penetration of energetic electrons in tissue-like matter; the model will be used to predict doses delivered to adjacent regions in which bystander cells may reside. Results are presented of calculations of the stochastics of energy deposition by 25 $\mathrm{keV}$ electrons slowing down in a homogeneous water medium. Energy deposition distributions were scored for 1-um spheres located at various penetration and radial distances up to 10um from the point of original. The energy of $25 \mathrm{keV}$ was selected because experiments are planned for energy. At $25 \mathrm{keV}$ there is a high probability that the entire electron track will be contained within a typical mammalian cell. Individual tracks are scored because of their primacy; data for higher doses can by obtained by convoluting single-track distributions. The event frequency decreases approximately exponentially after the first micrometer to $1 \%$ at about 8 um of penetration. Radially, the $1 \%$ contour extends to 3.5 um at a penetration of $5.5 \mathrm{up}$. The frequencymean energy deposited decreases from 1.5 to $1 \mathrm{keV} / \mathrm{up}$ at a penetration of $3.5 \mathrm{um}$, then increases back to about 1.5 at a penetration of $6.5 \mathrm{um}$. The mean energy increases to about $3 \mathrm{keV} / \mathrm{um}$ at a radial distance of $8.5 \mathrm{um}$.

Published in Radiation Research Vol. 144: 89-94; 2001.

\section{USTUR-0172-01A}

\section{Interstitial Lung Disease of Occupational Origin: A Case Report}

\author{
J. J. Russell \\ United States Transuranium and Uranium Registries, Washington State University, 2710 University Drive, Richland, \\ WA 99352.
}

Assessment of an illness attributable to an occupational or environmental exposure to radioactive materials is complicated since many human disorders in non-radiation workers display the same or similar clinical features. An autopsy of a former radiation laboratory worker, USTUR case 0420, indicated the primary cause of death as pulmonary insufficiency secondary to severe interstitial lung disease. Case 0240 worked as a sheet metal worker at the Rocky Flats facility in areas where the potential for exposure to beryllium, plutonium and uranium dust existed. Prior to his employment at Rocky Flats, he worked as a furnace installer and was routinely exposed to asbestos. He started smoking at the age of fifteen and smoked for 34 years at a rate of $1-1 \frac{1}{2}$ packs per day. Following the death of case 0240 in 1993, selected bone and soft tissue samples were collected at autopsy for radiochemical and pathological analysis. Additional lung tissue samples were sent to an independent laboratory for mineral analysis by histochemistry and electron microscopy (EM). Although extensive hemosiderin deposition throughout the lung tissue made it 
difficult to identify asbestos bodies, two classic beaded asbestos bodies were identified in five iron stained sections. Other lung tissue samples were digested on a filter with sodium hypochlorite and examined by light and EM microscopy. Compared to a background range of up to 1,000 asbestos bodies per gram of dry lung, one autopsy filter sample revealed 3,669 asbestos bodies per gram of dry lung. The first EM analysis disclosed an asbestos fiber concentration of 516,000 per gram of dry lung based on a detection limit of 258,000 fibers per gram of dry lung. A second EM analysis analyzed all fibers greater than $3 \mathrm{~mm}$ in length with a detection limit of 10,000 fibers per gram of dry lung. The second analysis revealed a total asbestos fiber concentration of 187,000 fibers per gram of sample. In addition the types of fibers detected were identified as: amosite, crocidolite, tremolite, and anthophylite. The pathologist concluded that the asbestos exposure and tissue content was sufficient to be the cause of the interstitial fibrosis and death. Both Pu and asbestos are known to cause interstitial lung fibrosis, preliminary radiochemical results are being analyzed to help determine to what extent radiation dose/dose rate was involved.

Abstract published in Health Physics Vol. 80:S111;2001.

\section{USTUR-0174-01}

\section{Fetoplacental Dosimetry of Plutonium Burdens Incurred Prior to Pregnancy}

\section{R. Sikov and J. J. Russell}

United States Transuranium and Uranium Registries, College of Pharmacy, Washington State University, 2710 University Drive, Richland, WA 99352

Concern with determining and controlling radiation doses associated with exposure of potentially pregnant women to radioactive materials in the workplace and in the environment have led to studies of fetoplacental disposition in several species of experimental animals. These studies have quantified placental transfer from the maternal blood circulation to the fetus and the results were used to derive gestational-stage-related kinetic models and dosimetric tables such as those in NUREG/CR-5631 Rev. 2 . The biokinetic models considered the limited data on plutonium concentrations in human fetoplacental tissue, which were obtained using tissues from members of the general population and so contained only background or environmental levels. The Registries have reported results from analyses of placental samples from a woman with a work history that involved an accidental plutonium intake 12 years before her pregnancy as well as placental samples from a non-industry worker. Despite the low actinide levels in these tissue samples, two independent blind comparisons using the ultra sensitive fission track analysis technique were able to identify marked differences in plutonium concentrations in the two cases. The concentration of plutonium in placental tissue from the exposed woman is about 8-fold higher than concentration in reference woman but concentration in placental tissues from the control was much lower than reference values. The placental concentration in the USTUR case was about 150 times higher than that in the control case. The body burden in the woman at the inception of 


\section{UNITED STATES TRANSURANIUM HND URANIUM REGISTRIES}

PHARMACEUTICAL SCIENCES

COLLEGE OF PHARMHCY

pregnancy and blood levels at each month of pregnancy were calculated on the basis of ICRP metabolic models. These values were used as basis to evaluate the various recommended approaches to dosimetry of the embryo/fetus in women who have a body burden of plutonium at the beginning of pregnancy. Although there are quantitative differences, the calculated values are in general accord with those predicted by published biokinetic models used for dosimetric estimations.

Published in Health Physics Vol. 8(6):S123; 2001.

\section{USTUR-0181-02A}

\section{Human Wound Site Tissue Contaminated With Actinide Material}

\section{J. J. Russell, United States Transuranium and Uranium Registries, Washington State University, 2710 University} Drive, Richland, WA 99352

An accident involving insults such as physical trauma can induce several types of wounds i.e. incisions, punctures, burns, lacerations and abrasions. Moments after the wound has occurred, disruption and destruction of local tissue morphology and histology and blood vessels initiates a cascade of events that lead ultimately to repair of the injury site. However, the exact nature or synergy of the physiological response that occurs when an acute wound produced by a cut, puncture, abrasion etc is accompanied by hot acidic or corrosive solutions that may or may not contain radioactive materials i.e. $\mathrm{Pu}, \mathrm{Am}$ or $\mathrm{U}$ is largely unknown. It is known however that cell sensitivity to radiation varies extensively throughout the cell cycle. As a consequence, cells alter their transit through the cell cycle after exposure to radiation. Such exposed cells may delay in G1, S, G2 or mitosis and thus affect the normal wound healing process. Consequently, chronic irradiation from extravasated deposits of thorium dioxide has induced delayed wound healing at the site of Thorotrast injections in some patients. However, how the resulting dose and or dose rate from embedded particles of actinide materials affect the overall multi-step wound repair process remains poorly understood. Pathological examination of wound site tissue contaminated with actinide material from three USTUR Registrant cases were examined to evaluate the wound site healing process following decades of low-level alpha irradiation in situ. Other than the thorotrastoma that developed at the site of Thorotrast injection, wound site tissue pathology in the other two-Registrant cases was normal. Radiochemical analysis of wound site tissue areas disclosed actinide values comparable to that level found in normal muscle and skin.

Abstract published in Health Physics Vol. 82(6):S165; 2002. 